\title{
AL-QUR'AN MENJAWAB TANTANGAN HAK ASASI MANUSIA
}

\section{Al-Qur'an Answering the Challenge of Human Rights}

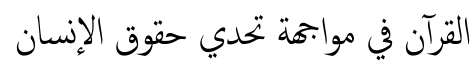

\author{
Munif Mahadi Attamimi ${ }^{1}$, Muhammad Hariyadi ${ }^{2}$ \\ ${ }^{1}$ Direktur Inkopsim (Induk Koperasi Syirkah Mu'awanah) Jakarta, Indonesia \\ optimis6467@gmail.com \\ ${ }^{2}$ Institut PTIQ Jakarta, Indonesia \\ m.hariyadi@ptiq.ac.id
}

\begin{abstract}
Abstrak
Kesimpulan dari penelitian ini menjelaskan mengenai hakekat kemuliaan martabat manusia yang melekat padanya sejak lahir dan proses kronologisnya. Al-Qur'an menerangkan dengan rinci dan runut bahwa pemuliaan martabat manusia terjadi dalam beberapa fase. Pertama adalah sebelum keberadaaannya dimuka bumi (alam ghaib): ketika Allah berkehendak menjadikan manusia khalifah (penguasa) di bumi, diperintahkannya para Malaikat untuk sujud kepada Adam sebagai suatu penghormatan, keunggulan, pemuliaan dan diajarkan ilmu secara menyeluruh. Kedua, ketika berada di dalam kandungan dimana sang janin di jaga dan terawat dengan baik dengan mendapat makanan bernutrisi melalui plasenta. Ketiga saat berada di dunia, diberikan bentuk tubuh yang sempurna, di mudahkan baginya untuk menguasai daratan dan lautan, diberikan hak untuk mengelola dunia dan seisinya, diberikan rezeqi yang baik-baik dan di muliakan dari makhluk ciptaaan Allah SWT lainnya. Keempat, dimuliakan pada saat meninggal, pemakaman dan setelah meninggal dunia. Untuk menjaga dan melindungi kemuliaan martabat manusia tersebut maka Allah telah menyiapkan tiga komponen penting bagi manusia sebagai landasan untuk melindungi hak asasi manusia (HAM) yaitu akidah, syariat dan akhlak. Metode yang digunakan dalam penafsiran yang berkaitan dengan penelitian ini adalah metode tematik atau maudui' yang digabungkan dengan metode kualitatif sebagai basis untuk riset kepustakaan, ayat Al-Qur'an, hadis syarif, jurnal, artikel, seminar dan prosiding konferensi.
\end{abstract}

Kata Kunci: Al-Qur'an, HAM, Akidah, Syariat dan Akhlak

\begin{abstract}
The conclusion of this study explains the nature of human dignity inherent in it from birth and its chronological process. The Al-Qur'an explains in detail and sequentially that the glorification of human dignity occurs in several phases. The first is before his existence on earth (unseen world): when Allah wants to make a human caliph (ruler) on earth, he orders the angels to prostrate to Adam as a respect, excellence, exaltation and knowledge are taught as a whole. Second, when in the womb where the fetus is well cared for and is well cared for by getting nutritious food through the placenta. Third, when he is in the world, he is given a perfect body shape, makes it easy for him to control the land and sea, is given the right to manage the world and everything in it, is given good sustenance, and is honored by other creations of Allah SWT. Fourth, be glorified at the time of death, at funerals, and after death. To maintain and protect the dignity of human beings, Allah has prepared three important components for humans as a basis for protecting human rights (HAM), namely faith, law, and morals. The method used in
\end{abstract}


interpretation related to this research is the thematic method or maudui 'which is combined with qualitative methods as a basis for library research, Al-Qur'an verses, hadith syarif, journals, articles, seminars, and conference proceedings.

Keywords: Al-Qur'an, HAM, Akidah, Sharia, and Morals

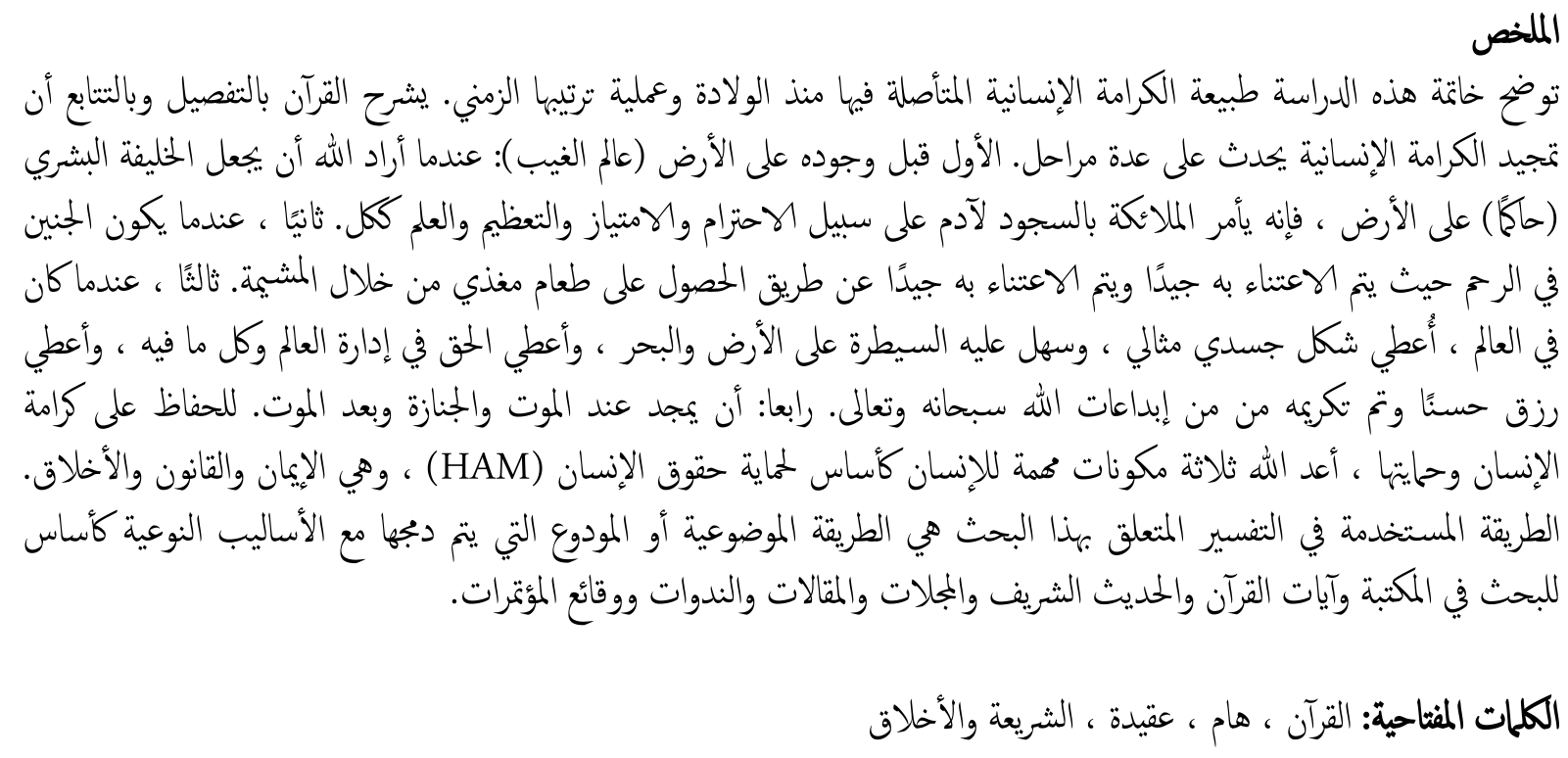

\section{Pendahuluan}

Perkembangan peradaban manusia yang ditandai oleh kemajuan tekonologi dan era komunikasi digital yang semakin canggih, telah banyak memberikan kemudahan bagi manusia dalam membangun hubungan dan interaksi dengan semua lapisan masyarakat. Namun hal demikian, dirasa masih belum memberikan konstribusi memadai untuk melakukan perbaikan terhadap pelanggaran hak asasi manusia $(\mathrm{HAM})^{1}$ dan melindunginya dari tindakan-tindakan yang tidak bertanggung jawab. Pemberitaan media digital dan koran-koran yang terbit berkaitan dengan pelanggaran hak-hak manusia kerap kali masih muncul, di tambah lagi data-data temuan di lapangan dan laporan yang masuk dari pengaduan kasus-kasus pelanggaran terhadap HAM, menunjukan masih belum adanya perbaikan terhadap pelanggaran hak-hak manusia.

Terjadinya pelanggaran terhadap hak asasi manusia tidak hanya ditemukan pada masyarakat dari suatu negara berkembang. Negara-negara majupun yang digolongkan kesadarannya HAM-nya telah tinggi punya pengaruh dan peran yang tidak kecil terhadap pelangaran tersebut. Menurut Beth A. Simmons dalam paparannya yang berjudul The Future of the Human Rights Movement bahwa gerakan hak asasi manusia modern belum mencapai nilai standard yang ingin dicapai meskipun telah tujuh puluh tahun sejak hak asasi manusia dideklarasikan dan banyak lembaga swadaya

1 A. Bazar Harahap dan Nawangsih Sutardi, Hak Asasi Manusia dan Hukumnya, (Jakarta: Pecirindo, 2007, Cet II), hal. 7. HAM diartikan sebuah hak yang melekat dan dimiliki oleh setiap manusia, dan oleh sebab demikian maka tidak diperkenankan untuk direduksi dengan alasan apapun.

51 | al-هurhan: Kajian Ilmu dan Pengembangan Budaya Al-Qur'an, Vol. 20, No. 1, Juni 2020: 50-79. 
masyakat (LSM) kemanusian bekerja untuk itu, namun hanya isu dan gaung hak asasi manusia telah yang menjadi semakin dikenal. ${ }^{2}$

Menguatkan pendapat diatas, sejalan apa yang dikatakan oleh Christopher J. Fariss bahwa hak asasi manusia selama dekade terakhir belum membaik meskipun penyebaran norma-norma hak asasi manusia dan pemantauannya lebih baik dalam era digitalisasi ini. ${ }^{3}$ Sementara dari laporan tahunan Komisi Nasional Hak Asasi Manusia (KomnasHAM) ${ }^{4}$ sepanjang tahun 2017, KomnasHAM telah menerima ribuan laporan berkas yang masuk ( 5.387 berkas). Dari laporan tersebut terdapat 3 (tiga) institusi yang paling sering di adukan oleh masyarakat sesuai pengelompokan pihak yang dilaporkan, yaitu Kepolisian (1.652 berkas), Korporasi (866 berkas), dan Pemerintah Daerah (597 berkas). Kepolisian, Korporasi, dan Pemerintah Daerah adalah 3 (tiga) institusi yang paling sering dikeluhkan dan banyak diadukan oleh masyarakat. Hal tersebut berlangsung terus menerus sekurang-kurangnya paling tidak selama 3 (tiga) tahun terakhir ini.

Keadilan merupakan permasalahan yang paling banyak dikeluhkan dalam laporan di atas dan masih sering dilanggar, berikutnya adalah permasalahan hak atas kesejahteraan yaitu hak ekonomi, sosial, kelayakan pendidikan, kesehatan, dan memperoleh pekerjaan. Hak-hak tersebut sebenarnya sudah dijamin oleh undangundang namun demikian realitasnya belum dapat diwujudkan sebagaimana yang diharapkan. Lembaga-lembaga selain KomnasHAM seperti Komnas Perempuan, Komite Perlindungan Anak Indonesia (KPAI) dan lain sebagainya mencatat hal yang sama termasuk masih maraknya korupsi yang secara tidak langsung lebih berbahaya karena mengurangi dan merampas hak-hak masyarakat sebagaimana laporan dari komite Pembaratasan Korupsi (KPK).

\section{Menjaga dan Melindungi HAM Berbasis Al-Qur'an 1. Pengertian Hak Asasi Manusia (HAM)}

Konsep dasar HAM secara umum dapat diartikan seperangkat hak yang melekat pada manusia sejak lahirnya yang merupakan haknya sebagai manusia dari pemberiaan Allah SWT. Hak yang melekat pada manusia yang disebut kemudian sebagai martabat manusia tidak dapat dicabut dan dihilangkan oleh siapapun juga termasuk oleh negara sekalipun. Dalam UU Hak Asasi Manusia (Pasal 1 ayat 1 UU No. 39 Tahun 1999 yang berkaitan dengan HAM) dijelaskan hak asasi manusia adalah hak dasar yang dimiliki manusia sesuai kodratnya sebagai manusia yang dibawa sejak lahir dan tidak dapat dihilangkan dan di hapus oleh siapapun juga karena merupakan

2 Beth A. Simmons, "The Future of the Human Rights Movement", Ethics E International Affairs 28, Iss. 2 ( 2014): 183-196

3 Christopher J. Fariss, "Respect for Human Rights has Improved Over Time: Modeling the Changing Standard of Accountability”, American Political Science Association, 108, no. 2 (2014)

4 https://www.komnasham.go.id, Laporan Tahunan Komnas HAM (LAPTAH), (diakses pada tanggal 27 November 2019), Komnas HAM didirikan Pada tanggal 7 Juni 1993 Presiden Republik Indonesia saat itu, Soeharto, lewat Keputusan Presiden No. 50 Tahun 1993, Kedudukan Komnas HAM kemudian mempunyai kekuatan hukum yang lebih kuat dengan diundangkannya Undang-Undang Nomor 39 Tahun 1999 tentang Hak Asasi Manusia (UU 39/1999). Berdasarkan Pasal 1 angka 7 UU 39/1999, KomnasHAM adalah "lembaga mandiri yang kedudukannya setingkat dengan lembaga negara lainnya yang berfungsi melaksanakan pengkajian, penelitian, penyuluhan, pemantauan, dan mediasi hak asasi manusia. 
pemberiaan dan karunia oleh Allah SWT. ${ }^{5}$ Oleh karena itu setiap orang, masyarakat terutama pemerintah wajib menjaga, melindungi dan menjujung tinggi hak-hak dan martabat manusia.

Perbedaan yang melatar belakangi keberadaan manusia seperti warna kulit, keyakinan, budaya adalah merupakan bagian hak-hak manusia yang merupakan sebuah keniscayaan yang harus dihormati dan diakui keberadaannya sebagai bagian dari hak asasi manusia. Implikasinya adalah setiap orang berkewajiban untuk mempertahankan, membela, menjaga dan melindunginya dari unsur-unsur yang akan mengganggunya.

\section{Perkembangan Hak Asasi Manusia}

Masalah HAM menjadi isu yang menarik dan aktual karena menyangkut dengan permasalahan seluruh umat manusia sebagai subyek dan obyek HAM. Perlakuan dari ketidak wajaran terhadap hak asasinya manusia seperti hilangnya rasa keadilan untuk mendapatkan perlindungan harkat dan martabat kemanusiaan yang universal merupakan problem dasar yang belum tuntas untuk diselesaikan. Sejarah Ham bermula dengan:

a. Pengutusan Muhammad Sebagai Rasul

Diutusnya Nabi Muhammad SAW karena hak-hak manusia sudah dibatas titik nadir dan manusia hampir mengalami kepunahan. Oleh karena itu diperlukan seseorang yang dapat menyelamatkan umat manusia secara keseluruhan dan membawa nilai-nilai kemanusiaan yang dituangkan dalam konsep yang jelas sebagai panduan seluruh umat manusia. Dalam bukunya Emotions As The Basis Civilization yang dikutip oleh Dato Haron Din dalam bukunya Rujukan Efektip Akhlak Mulia, Prof. Dinson menyatakan:"Dunia berada tepi kehancuran ketika Islam datang. Pada masa itu kelompok-kelompok, suku-suku, bangsa-bangsa ras manusia saling berperang satu sama lainnya, sehingga betul-betul hampir mengakibatkan dampak kerusakan dan kepunahan pada penduduk dunia; nilai-nilai atau peradaban tidak ada yang dapat di agungkan. Dunia sudah di ambang jurang kebinasaan pada abad ke lima dan ke enam karena agama sudah tidak berperan lagi dan dihancurkan. Kehidupan ketika itu hanya di isi dengan peperangan antara suku, kabilah, kelompok dan bangsa. Aturan main berupa undang-undang dan nilai tidak ada yang dapat dipegang. Sementara agama Nasrani yang dibawa oleh Nabi Isa as sebagai penerus agama sebelumnya mengalami hal yang sama juga yaitu kehancuran. Dari kehancuran dan kerusakan yang hampir sempurna itu sebagaimana dijelaskan di atas dilahirkan seorang anak laki-laki yang ditugaskan membawa obor keselamatan dan menjadi solusi jalan keluar terhadap semua penyakit manusia". ${ }^{6}$

Misi kerasulan Muhammad SAW dan semua Rasul sebenarnya adalah untuk menegakan dan melindungi Hak Asasi Manusia. Mereka adalah pejuang yang gigih dan siap untuk mengorbankan nyawa dan apapun yang dimiliki demi tugas yang diemban berupa risalah demi tegaknya hak asasi manusia. Hal ini ditegaskan dalam ayat Al-Qur'an sebagai berikut,

${ }^{5}$ Baharudin Lopa, Al-Qur'an dan Hak Asasi Manusia (Yogyakarta: Dana Bakti Prima Yaksa 1996),

1.

${ }^{6}$ Dato Haron Din, Rujukan Efektip Akhlak Mulia (Sabah:Publishing House, 2007), 111.

53 | al-§urhan: Kajian Ilmu dan Pengembangan Budaya Al-Qur'an, Vol. 20, No. 1, Juni 2020: 50-79. 


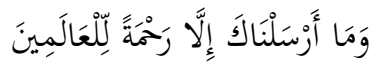

Dan tiadalah Kami mengutus kamu, melainkan untuk (menjadi) rahmat bagi semesta alam. (al-Anbiya'/21:107)

Menurut al-Razi dalam menjelaskan ayat di atas, Rasulullah merupakan sosok yang mendatangkan rahmat baik di dunia maupun di akherat kelak. Pada saat datangnya Rasul membawa risalahnya keberadaan manusia pada waktu itu berada dalam kegelapan dan kebodohan (jahiliyyah). Para pemuka agama (ahlul kitab) merasa tidak tahu mesti berbuat apa karena berada dalam kebingungan, sementara perselisihan dan perbedaan sesama mereka terus berlanjut dalam menyikapi kitab mereka yang sudah hilang keaslianya (putusnya kemutawatiran). Pada suasana kegelapan yang pekat menyelemuti manusia maka Allah SWT mengutus Nabi Muhammad Shallallahu 'alaihi wa sallam untuk membersihkan manusia dari kehancuran, kehinaan, pertentangan, peperangan sesama mereka dan membawa mereka kepada cahaya tauhid. ${ }^{7}$ Sementara rahmatan lil'âlamin yang dimaksud diatas paling tidak berkaitan tiga hal pokok, pertama berkaitan dengan manusia seperti disebutkan diatas baik kafir (non muslim) maupun muslim atau kulit putih maupun kulit hitam, kedua berkaitan dengan perlakuan terhadap binatang atau hayawan.

Imam al-Bukhâri yang merupakan seorang Amîrul Mu'minin fì hadis, telah membuat dan memilih sebuah nama yang dijadikannya dalam judul bab pada bagian Kitâbul Adab yang terdapat di dalam kitab shahihnya, yang diberi judul dengan : Bâbu Rahmatin Nâs wal Bahâ'im yang diartikan sebagai: "Bab Mengasihi/menyayangi manusia dan hewan" dimana memuat hadis-hadis rahmat di dalamnya. ${ }^{8}$ Kemudian yang ketiga adalah menyangkut pengelolaan lingkungan hidup sebagaimana dalam salah satu hadisnya Nabi Muhammad SAW menganjurkan umatnya untuk melestarikan lingkungan hidup lewat reboisasi. ${ }^{9}$

\footnotetext{
${ }^{7}$ Fakhruddin ar-Razi, Mafatih al-Ghaib (Beirut: Darul Fikr, 1981), 230-231.

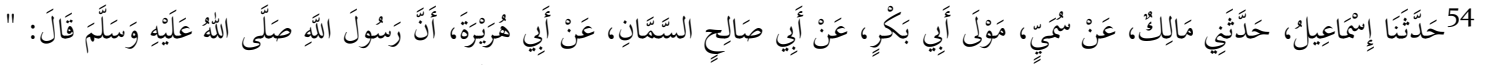

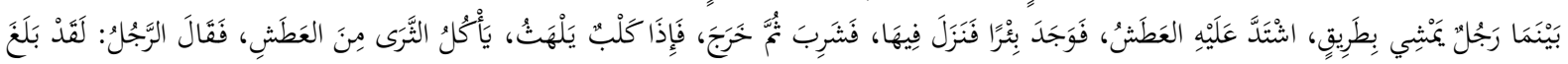

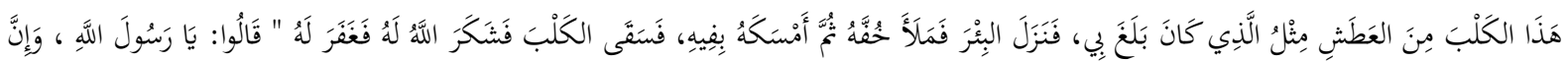

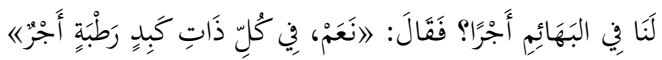

Dari Abu Hurairah Radhiyallahu anhu (dia berkata): Sesungguhnya Rasûlullâh Shallallahu 'alaihi wa sallam telah bersabda, "Ketika seorang laki-laki sedang berjalan di suatu jalan, dia sangat kehausan sekali, lalu dia mendapati sebuah sumur, segera dia turun ke sumur itu dan meminum (airnya). Kemudian ketika dia keluar dari sumur, tiba-tiba ada seekor anjing yang sedang menjulurkan lidahnya sembil menjilati tanah karena kehausan. Laki-laki itu berkata, Sesungguhnya anjing ini telah menderita kehausan seperti yang pernah aku rasakan tadi". Lalu laki-laki itu turun kembali ke sumur, kemudian dia penuhi sepatu botnya dengan air, (setelah itu dia keluar dari sumur) sambil menggigit sepatu botnya dengan mulutnya. Kemudian dia minumkan ke anjing itu, maka Allâh bersyukur kepadanya dan mengampuni (dosa-dosa)nya". Para Shahabat bertanya: "Wahai Rasûlullâh, sungguhkah (apakah) kita akan mendapat pahala apabila kita berbuat kebaikan kepada binatang?" Beliau Shallallahu 'alaihi wa sallam menjawab, "Pada setiap mahluk yang hidup apabila kamu berbuat kebaikan kepadanya, maka kamu akan mendapat pahala. (HR. al-Bukhari-Imam Bukhâri, Saĥh $\underline{h}$ Bukhâri, juz 8 hal. 9, no. hadis 6oo9, bab Mengasihi/menyayangi manusia dan hewan.)

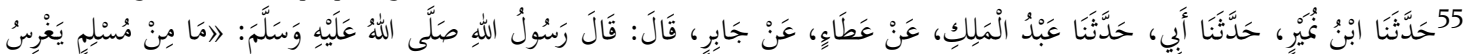

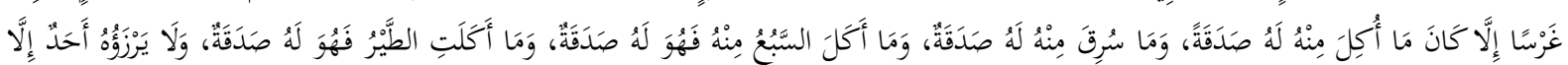

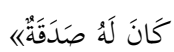


Salah satu aplikasi dari perwujudan rahmatal lilalamin dapat dilihat pada dokumen Piagam Madinah yang berisi empat puluh dua pasal yang berisi aturanaturan yang mengingkat terhadap masyarakat yang majemuk. Piagam Madinah (shahifatul madinah / mitsaaqu al-Madiinah) merupakan dokumen atau konstitusi pertama di dunia yang hadir pada saat itu dimana di dalamnya Nabi Menyusun pasal demi pasal yang dapat diterima dan memuaskan semua semua pihak yang berada di kota Madinah (Yasrib) sebagai ikatan perjanjian sebagai warga negara yang masingmasing punya hak dan kewajiban. Piagam Madinah menjadi ikatan dan perjanjian formal antara Nabi Muhammad SAW dan penduduk Madinah yang terdiri dari sukusuku dan tokoh-tokoh penting serta perbedaan keyakinan, terutama untuk menghindari pertumpahan darah antara Bani 'Aus dan Bani Khazraj, serta untuk mengikat kaum Yahudi dan kaum Paganisme lainnya, menjadi satu kesatuan yaitu "Ummah".

Sejatinya Islam tidak pernah memilih dan memilah dalam memandang komunitas atau kelompok yang terdapat dalam masyarakat, bahkan Islam memandang dari sisi manusianya yang merupakan ras tunggal dan sebagai makhluk ciptaan Allah SWT yang paripurna. Perbedaan yang ada seperti warna kulit, keyakinan, budaya dan selain sebagainya, merupakan sunnatullah atau ketentuan dari Allah SWT yang mesti disikapi dengan arif. Hal diatas mendapat penegasan dari AlQur'an dalam ayat al-Hujurat/49:13 sebagai berikut:

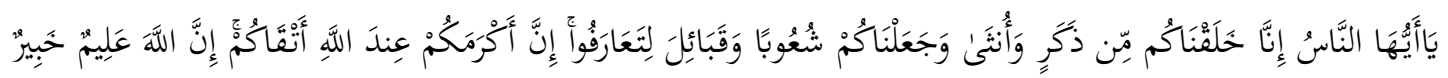

Hai manusia, sesungguhnya Kami menciptakan kamu dari seorang laki-laki dan seorang perempuan dan menjadikan kamu berbangsa-bangsa dan bersuku-suku supaya kamu saling kenal-mengenal. Sesungguhnya orang yang paling mulia diantara kamu disisi Allah ialah orang yang paling takwa diantara kamu. Sesungguhnya Allah Maha Mengetahui lagi Maha Mengenal.

Ayat di atas menarik, disamping muatannya bersifat universal, asbabu nuzulnya beragam namun semuanya menafikan kasta-kasta dan perbedaan latar belakang yang dapat menodai hak asasi manusia. Riwayat pertama menegaskan bahwa ayat ini turun berkenaan dengan perintah Nabi Muhammad SAW kepada Bani Bayadhah untuk menikahkan salah satu putri mereka dengan Abu Hind, seorang pembekam Nabi Muhamad SAW dan bekas budak. Namun permintaan tersebut tidak dapat dipenuhi dengan memberi alasan bahwa Abu Hind adalah seorang bekas budak yang tidak

Dari Anas r.a. berkata: Rosulullah shallallâhu 'alaihi wasallam bersabda : Seseorang muslim tidaklah menanam sebatang pohon atau menabur benih ke tanah, lalu datang burung atau manusia atau binatang memakan sebagian dari padanya, melainkan apa yang dimakan itu merupakan sedekahnya “. (HR. Muslim-Imam Muslim, Saḥ̂h Muslim, juz 3, hal. 1188, no. hadis 1553, bab Keutamaan Merawat dan Menanam).

Sejalan dengan keterangan di atas, hadis yang diriwayatkan Abu Dawud menguatkan pendapat di atas, Dari Sahl bin Handzaliyyah, dia berkata, "Rasûlullâh Shallallahu 'alaihi wa sallam pernah melewati seekor onta yang punggungnya telah merapat ke perutnya, maka beliau bersabda, "Takutlah kamu kepada Allâh terhadap binatang-binatang ini yang tidak dapat berbicara kepada kamu, naikilah dia dengan baik dan (kalau tidak dikendarai) maka biarkanlah (istirahatkanlah) dia dengan baik.” (Abu dawûd, Sunan Abî Dawûd, Juz 3, hal. 2, no hadis, 2548, bab Kewajiban yang harus dilakukan terhadap Binatang) 
layak untuk diterima lamarannya. Riwayat kedua berkaitan dengan Bilal bin Rabbah ketika menjadi muazzin menyerukan shalat dari atas Ka'bah pada saat fathu Mekah (penaklukan kota Mekah). Maka sebagian orang dari penduduk Mekah berkata: apakah yang menyeru azan itu adalah seorang budak hitam?, riwayat lain menyebutkan mereka berkata dengan mengejek apakah nabi Muhammad tidak mendapatkan yang lain selain burung "gagak hitam" ini. Riwayat ketiga menurut pendapat yang lain, ayat tersebut diturunkan berkenaan dengan Tsâbit bin Qâis bin Syamas dan perkataannya terhadap orang yang tidak mau menyediakan tempat untuk dirinya: "Anak si fulanah,"kemudian Nabi berujar: "Siapa yang mengatakan Fulanah?" Tsâbit menjawab, "Saya, wahai Rasulullah". Kemudian Nabi berkata kepadanya, "Pandanglah wajah orang-orang tersebut". Tsâbit kemudian memandang (wajah mereka), kemudian Rasulullah berkata, "Apakah yang kamu pandang?" Tsâbit menjawab," Hitam, merah, Putih, yang saya pandang." Nabi berkata,"Sesungguhnya kamu tidak bisa melebihi mereka kecuali hanya melalui ketakwaan".

Maka ayat di atas diturunkan berkenaan dengan Tsâbit, sedangkan untuk orang yang tidak mau menyediakan tempat terhadapnya diturunkan ayat di surah alMujâdalah/58:11. ${ }^{10}$

\section{b. Magna Charta}

Kemunculan piagam Magna Charta tahun 1512 yang terjadi di Inggris memberikan pembatasan yang jelas bahwa raja yang memegang tampuk kekuasaan secara mutlak (membuat hukum tersendiri) tidak dapat lagi berbuat semena-mena dan harus bisa mempertanggungkan jawabkan segala bentuk administrasi kenegaraan yang dilakukannya. Hal ini dapat diartikan bahwa raja dapat dihukum apabila melanggar peraturan yang berlaku.

\section{c. The French Declaration}

Pada tahun 1789 muncul The French Declaration yaitu suatu pernyataaan deklarasi tentang Hak Asasi Manusia yang berkaitan dengan sikap warga negara Perancis yang menekankan larangan penangkapan tanpa alasan yang jelas dan semena-mena, penahanan orang tanpa bukti dan tanpa keputusan hukum, kebebasan mengeluarkan pendapat, pengaturan hak milik (the right of property), kebebasan memeluk agama (freedom of religion), dan asas praduga tak bersalah (presumption of innonce). ${ }^{11}$

\section{Teori Hak-Hak Kodrati ( Natural Rights Theory)}

Konsep Hak Asasi Manusia yang berkembang sekarang ini merujuk pada teori kodrati (natural rights theory) yang dibangun dan digagas oleh John locke yang hidup pada abad 1632-1704 yang berlandaskan teori hukum kodrati (natural law theory). Dalam teori tersebut John Locke menegaskan postulasi pemikirannya bahwa setiap orang di anugrahkan hak oleh alam yang melekat padanya yaitu hak untuk hidup, hak kebebasan dan hak memiliki, yang tidak dapat dicabut dan dihilangkan oleh siapapun

\footnotetext{
${ }^{10}$ Imam Qurtubi, al-Jāmi' li Ahkām al-Qur'ān (Qahirah: Darul Kutub al-Misriyyah 1964), 341.

${ }^{11}$ Eggi Sudjana, Hak dalam Perspektif Islam, Mencari Universalitas HAM bagi Tatanan Modernitas yang Hakiki (Jakarta, Penerbit Nuansa Madani 2001), 5.
} 
juga termasuk negara. Untuk menjaga hak-hak tersebut John Locke mengajukan teori kontrak sosialnya; jika suatu negara mengabaikan dan melanggar hak-hak alamiah yang sebagaimana disebutkan di atas maka rakyat berhak mengganti dan menurunkan penguasa untuk menggantinya dengan pemerintah yang dapat menjaga, melindungi dan menghormati hak-hak kodrati tersebut. Munculnya revolusi yang meletup di Inggris, Amerika Serikat dan Perancis pada abad ke-17 dan ke-18 adalah implikasi dari pengaruh teori kodrati tersebut. ${ }^{12}$

Hampir semua istilah dan definisi hak asasi manusia yang ada sekarang ini semuanya mengacu pada istilah dari teori hak kodrati (alamiah) yang dibangun oleh John Locke meskipun redaksinya berbeda-beda. Namun demikian teori tersebut mengalami kebuntuan untuk menjelaskan proses dan kronologis hak-hak alamiah atau kodrati diperoleh oleh manusia sejak lahirnya yang pada akhirnya mengatakan hanya sebatas pemberian alam atau hak kodrati ataupun mereka yang masih percaya pada Tuhan mengatakan sebagai pemberian Tuhan. Penulis akan menyempurnakan teori di atas dengan menjelaskan proses dan kronologis hak alami atau kodrati sebagai sebuah martabat dan harkat pemuliaan manusia yang diperolehnya sejak lahir. Penulis menggali dan menukilnya dari sumbernya secara langsung yaitu dari kitab suci AlQur'an. Paling tidak ada empat fase pemuliaan martabat dan harkat manusia yang dijelaskan oleh Al-Qur'an; pertama, fase alam ghaib, kedua, fase ketika berada di kandungan, ketiga, saat kehidupana di dunia, keempat, saat meninggal dan penguburan, dan setelah meninggal dunia.

\section{a. Fase Alam Ghaib}

1) Menjadikan Manusia Khalifah (Penguasa)

Manusia dalam perspektif Islam telah ditetapkan sebagai makhluk Allah SWT yang memiliki kedudukan tertinggi, bermartabat dan mulia. ${ }^{13}$ Kemuliaan dan kehormatan yang telah disematkan kepada manusia mengindikasikan sebagai asal usul dari semua hak-hak yang melekat pada manusia dan merupakan tanda-tanda yang membedakannya dengan makhluk-makhluk selainnya. Karena itu sejak awal penciptaan manusia dimaksudkan untuk memuliakan dan mengangkat martabatnya dengan mendudukan dan menempatkan manusia sebagai penguasa (khalifah) di muka bumi. Kemuliaan martabat ini ditegaskan dalam Al-Qur'an dalam surat al-Baqarah/2:30 sebagai berikut,

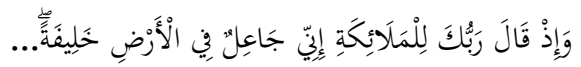

Ingatlah ketika Tuhanmu berfirman kepada para Malaikat: "Sesungguhnya Aku hendak menjadikan seorang khalifah di muka bumi"...

Pengertiaan makna khalifah $^{14}$ pada ayat di atas adalah pengangkatan dan menempatkan manusia sebagai penguasa di muka bumi dan diberikan hak otoritas untuk mengelola dan memanfaatkan bumi dengan seluruh isinya untuk

${ }^{12}$ Rhona K. M. Smith, dkk, Hukum Hak Asasi Manusia (Yogyakarta: PUSHAM UII, 2008), 12,

${ }^{13}$ Masdar F. Mas'udi, Hak Asasi Manusia dalam Islam, dalam E. Sobirin Nadj dan Naning Mardiyah, Diseminasi HAM dalam Perspektif dan Aksi, (Jakarta:Cesda LPES, hal. 66)

${ }_{14}$ Terdapat banyak pengertian dan pendekatan yang dilakukan untuk mengurai makna khalifah baik ditinjau dari aspek kebahasaan maupun istilah, antara lain pendekatan dari aspek politik dalam hal ini kekuasaan (terdapat dalam surat al-Shad), kepemilikan (dalam surat al-hadid) dan pemuliaan (dalam surat al-Baqarah/2-30) dengan beragam interpretasinya.

57 | al-\$urhan: Kajian Ilmu dan Pengembangan Budaya Al-Qur'an, Vol. 20, No. 1, Juni 2020: 50-79. 
mendukung kehidupan mereka di dalamnya dan membangun relasi dengan sesama mereka serta lingkungannya. Karena itu hubungan yang dibangun dengan sesama mereka dan lingkungannya bukan sebagai antara tuan dan budak, orang yang berkuasa dan bawahan atau penakluk dan yang ditaklukan, tetapi hubungan yang dibangun atas dasar kebersamaan dan kesetaraan dalam rangka memakmurkan bumi dan mengambil manfaatnya tanpa harus merusaknya, hal ini digambarkan oleh Al-Qur'an sebagai berikut,

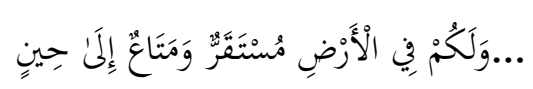

dan bagi kamu ada tempat kediaman di bumi, dan kesenangan hidup sampai waktu yang ditentukan. (al-Baqarah/2:36)

Terdapat yang hal yang penting dalam ayat di atas sebagai kata kunci untuk memahaminya yaitu mustaqarrun (tempat tinggal) dan mata' (bersenang-senang) sebagai daya dukung kehidupan bagi manusia dan hak milik bersama untuk tetap bertahan hidup (survive) dan memakmurkannya. ${ }^{15}$

2) Penciptaan Manusia Langsung dari Allah SWT

Penciptaan manusia berbeda dengan makhluk lainnya ciptaan Allah SWT karena sebagai makhluk yang punya bentuk dan struktur sempurna sudah barang tentu penciptaannya punya kekhususan dan keistimewaaan tersendiri. Hal ini ditegaskan dalam firman Allah SWT sebagai berikut,

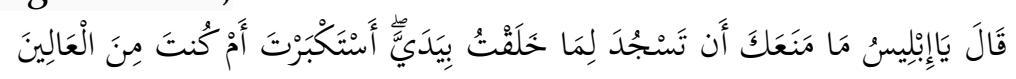

Allah berfirman: "Hai iblis, apakah yang menghalangi kamu sujud kepada yang telah Ku-ciptakan dengan kedua tangan-Ku. Apakah kamu menyombongkan diri ataukah kamu (merasa) termasuk orang-orang yang (lebih) tinggi?".

Dalam tafsir al-Qurtubi dijelaskan bahwa penyebutan "kedua tanganku" dalam penciptaan manusia merupakan suatu kemuliaan dan kehormatan bagi manusia sebagai hamba Allah SWT yang mempunyai martabat mulia. Dan masih menurut al-Qurtubi sebagaimana disebutkan juga oleh Qurais Shihab bahwa yang dimaksud penciptaan manusia dengan kedua tanganku adalah maksudnya tanpa perantara. ${ }^{16}$

3) Sujudnya Malaikat kepada Manusia

Dasar awalnya manusia adalah makhluk yang unggul, mulia dan bermatabat yang diberikan limpahan materi dan maknawi karena tujuan penciptaan manusia sejak mulanya memang untuk memuliakan dan mengangkat martabat manusia sebagaimana diterangkan dalam Al-Qur'an sebagai berikut,

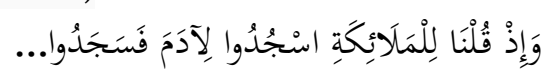

Dan (ingatlah) ketika Kami berfirman kepada para malaikat: "Sujudlah kamu kepada Adam," maka sujudlah...(al-Baqarah/2:34)

Sujudnya Malaikat kepada Adam atas perintah Allah SWT yang merupakan sebagai suatu penghormatan, menunjukan keunggulan dan kemuliaan Adam atas Malaikat serta merupakan karunia yang besar sekali. Sujud Malaikat dapat dipandang semata-mata sebagai suatu penghormatan karena penciptaan manusia.

4) Diajarkan Ilmu

\footnotetext{
${ }^{15}$ Fakhruddin ar-Razi, Mafatih al-Ghaib, (Bairut: Darul Ihyaa Turas Arabi 1420 h), juz 3, hal 464

${ }^{16}$ Imam al-Qurtubi, al-Jāmi' li Ahkām al-Qur'ān (Qahirah: Darul Kutub al-Misriyyah 1964), 228.
} 
Pemuliaan martabat manusia yang diberikan oleh Allah SWT kepada manusia adalah dikaruniakannya ilmu pengetahuan kepadanya sebagaimana dijelaskan dalam firman-Nya sebagai berikut,

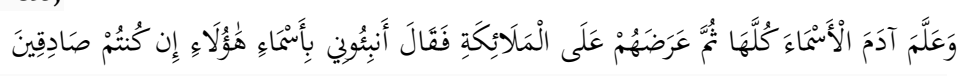

Dan Dia mengajarkan kepada Adam nama-nama (benda-benda) seluruhnya, kemudian mengemukakannya kepada para Malaikat lalu berfirman: "Sebutkanlah kepada-Ku nama benda-benda itu jika kamu mamang benar orang-orang yang benar!" (al-Baqarah/2:31)

Ayat di atas menjelaskan dari salah satu aspek keutamaan manusia adalah diajarkannya ilmu pengetahuan berupa semua nama benda-benda yang akan dapat dimanfaatkan untuk bekal mengelola bumi sehingga dapat memudahkan semua proses kehidupan di dalamnya dan manusia dapat menempatinya sebagai hunian yang layak tinggal. Ayat di atas juga merupakan jawaban terhadap Malaikat ketika mereka ditantang untuk menyebutkan nama benda-benda yang diajarkan kepada Adam, namun mereka tidak dapat menjawabnya bahkan dengan sopan Malaikat mengakui kelemahan mereka dan mengakui keunggulan Adam. ${ }^{17}$ Ayat di atas memberikan isyarat bahwa ilmu yang diterima oleh Malaikat tidak lebih banyak ketimbang yang diajarkan kepada Adam. Inilah disadari oleh Malaikat dengan menerima kelemahan-kelemahan mereka seraya mengakui bahwa Adam adalah manusia yang layak untuk menjadi khalifah (penguasa) di bumi.

b. Alam Rahim (Kandungan)

Al-Qur'an sejak awal turunnya empat belas abad yang lalu telah menjelaskan proses pembuahan yang berkaitan dengan lahirnya anak manusia. Tahapan perkembangan manusia melalui fertilasi telah dijelaskan oleh Al-Qur'an sebelum ilmu kedokteran mengungkapkannya. Tahapan-tahapan pertumbuhan janin yang berada di dalam Rahim diterangkan oleh Al-Qur'an dengan jelas dan akurat yang dibagi dalam tujuh fase sebagai terdapat penjelasannya dalam surat alMu'mukminun ayat 12-14 sebagai berikut,

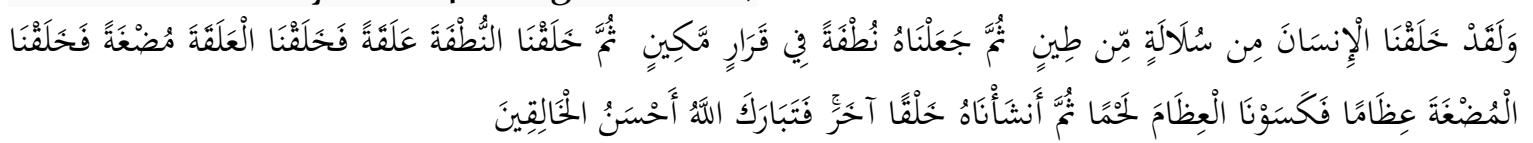

Dan sesungguhnya Kami telah menciptakan manusia dari suatu saripati (berasal) dari tanah. Kemudian Kami jadikan saripati itu air mani (yang disimpan) dalam tempat yang kokoh (rahim). Kemudian air mani itu Kami jadikan segumpal darah, lalu segumpal darah itu Kami jadikan segumpal daging, dan segumpal daging itu Kami jadikan tulang belulang, lalu tulang belulang itu Kami bungkus dengan daging. Kemudian Kami jadikan dia makhluk yang (berbentuk) lain. Maka Maha sucilah Allah, Pencipta Yang Paling Baik. (al-Mukminun/23:12-14)

Ayat di atas menjelaskan ada tujuh fase pembentukan manusia yang harus dilalui dalam pembentukan sampai menjadi manusia yang sempurna. Fase-fase ini dijelaskan oleh Al-Qur'an dengan jelas dan rinci. Hal ini sejalan dan sesuai dengan perkembangan ilmu emberiologi dari ilmu kedokteran.

${ }^{17}$ https://quran.kemenag.go.id/, Tafsir Depag Online, (di akses pada tanggal 20 Desember 2020) 
Fase pertama dari proses penciptaan anak Adam adalah dengan saripati tanah sebagaimana penjelasannya dalam surat Shad: 71. Fase kedua melalui air mani (nuthfah) yaitu pertemuan atau campuran antara sel sperma laki-laki dan perempuan sebagaimana dijabarkan dalam surat al-Fathir: 11. Fase ketiga adalah segumpal darah ('Alaqah) yang menjadi cikal bakal dan persiapan untuk pembentukan organ tubuh, 'Alaqah adalah segumpal daging menempel di dinding rahim. Keterangan ini terdapat dalam surat al-'Alaq ayat kedua. Fase keempat perkembangannya berubah menjadi segumpal daging (mudhgah). Pada fase ini juga terbentuk jaringan plasenta yang terhubung dengan tali pusar untuk membawa nutrisi dan oksigen kepada janin.

Pada fase ini pertumbuhannya telah mencapai empat bulan atau seratus dua puluh hari sebagaimana dijelaskan dalam suatu hadis Nabi Shallallahu 'alaihi wa sallam bahwa Allah SWT meniupkan ruhnya melalui Malaikat dan catatan perjalanan hidupnya. Fase kelima adalah pembentukan tulang ('Idzam) dimana jaringan tulang berkembang dan terbentuk menjadi tulang tengkorak, tulang belakang, punggung dan struktur tulang lainnya yang sempurna sehingga bentuk janin akan mulai terlihat rupanya.

Fase keenam adalah pembukusan tulang dengan daging (Kisa al-'Idzam billahm). Arti Kisa al-'Idzam bil-lahm adalah tulang yang telah terbentuk dan terstruktur dibungkus dengan daging, seperti kain yang membungkus tulang. Jadi, setelah sel-sel tulang terbentuk dengan sempurna diikuti dengan dengan terbentuknya jaringan sel-sel daging.

Fase ketujuh adalah perwujudan manusia (Insya'). Pada fase ini perubahan janin akan berbentuk makhluk lain yakni semua organ-organ sudah mulai seimbang dan sempurna dengan system syaraf dan sel-sel tubuh sudah mulai bekerja penuh. Janin sudah mulai disiapkan untuk berpindah alam yaitu kealam kehidupan nyata diluar alam Rahim. Di dalam alam Rahim janin tumbuh berkembang dengan sempurna, terawat dan terjaga dengan baik dengan mekanisme dan sistem yang sudah disiapkan oleh Allah SWT bagi manusia sehingga lahir sebagai manusia yang siap untuk menjadi khalifah (penguasa) di muka bumi. ${ }^{18}$

c. Alam Kehidupan Dunia

Sebagai penguasa atau khalifah di muka bumi sejatinya manusia sudah disiapkan dan diberikan beragam fasilitas dan kemudahan untuk menunjang semua kegiatan dan aktivitasnya di muka bumi. Pemuliaan dan pengangkatan harkat martabat manusia tegas-tegas dinyatakan oleh Al-Qur'an sebagaimana tertuang dalam surat al-Isra':

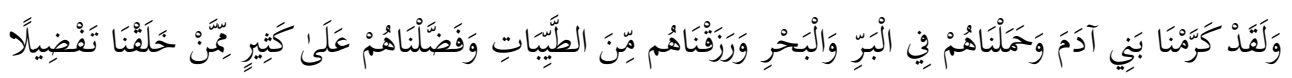

Dan sesungguhnya telah Kami muliakan anak-anak Adam, Kami angkut mereka di daratan dan di lautan, Kami beri mereka rezeki dari yang baik-baik dan Kami lebihkan mereka dengan kelebihan yang sempurna atas kebanyakan makhluk yang telah Kami ciptakan. (al-Isra'/17:70)

${ }^{18}$ Muhammad al-Amin bin Muhammad al-Mukhtar al-Jakni al-Syanqithy, Adhwau al-Bayan $f i$ Idhah al-Qur'an bi al-Qur'an, (Bairut: Darul Fikr, 1995), juz 5, hal 324. 
Ayat di atas menegaskan tentang kemuliaan dan ketinggian martabat manusia yang telah dianugrahkan oleh Allah SWT kepada manusia. Ayat di atas menyebut dengan Bani Adam yang mengandung arti anak Adam atau keturunan Adam, ini menunjukkan hakekat manusia sebenarnya adalah mulia, unggul dan bermatabat tanpa memandang latar belakang baik manusia dari yang beragama Islam maupun kafir (non muslim); tanpa melihat keyakinan, warna kulit, budaya maupun bahasa dan lain sebagainya. Manusia ditegaskan oleh Al-Qur'an adalah makhluk yang pada dasarnya mulia, terhormat dan unggul.

Ayat atas menjelaskan empat keterangan penting berkaitan dengan martabat kemuliaan yang diperoleh oleh manusia dari Allah SWT. Pertama, memuliakan manusia dari makhluk lainnya ciptaan Allah dari segi penciptaan dimana proses penciptaan manusia ditangani langsung oleh Allah dengan melalui beberapa fase dan tahapan serta ditiupkan ruhullah kepadanya sebagaimana sudah disinggung di atas khususnya terdapat dalam surah al-Mukminun. Sedangkan penciptaan makhluk selain manusia hanya melalui perkataan Allah kun, (jadilah). ${ }^{19}$

Sementara Imam Fakhruddin Al-Razi (544-704 H) menjelaskan dalam tafsirnya bahwa hakekat manusia adalah tersusun dari elemen yang paling lembut dan halus (jauhar) yaitu dari jiwa (nafs) dan jasmani (tubuh). Jiwa dan jasmani manusia adalah paling unggul, terhormat dan mulia. Ada lima ciri manusia menurutnya; makan, berkembang, berkembang biak, memiliki perasaan(alhasasah) dan dinamis. ${ }^{20}$

Lebih jauh menurutnya dan yang lebih penting bahwa manusia dibekali kecerdasan dan kekuatan intelektual agar dapat menguak dan mengungkap hakekat sesuatu. Dari sinilah manusia dapat menangkap cahaya kebenaran dan nur ilahi serta menolak segala keburukan-keburukan. Pendapat lainnya mengatakan manusia dimuliakan dengan kesempurnaan fisik dan non fisiknya, berjalan dengan

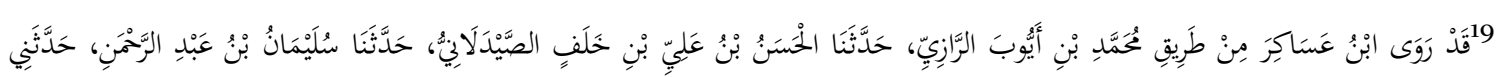

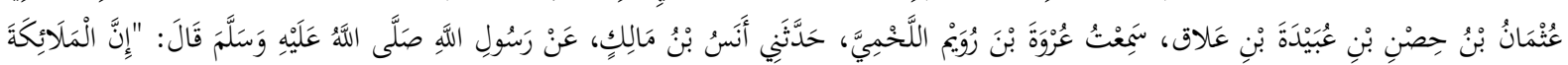

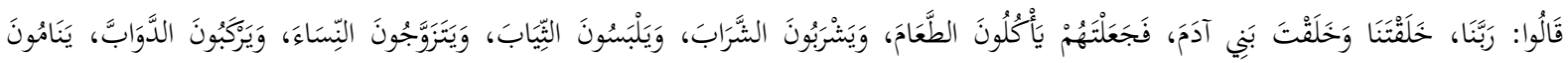

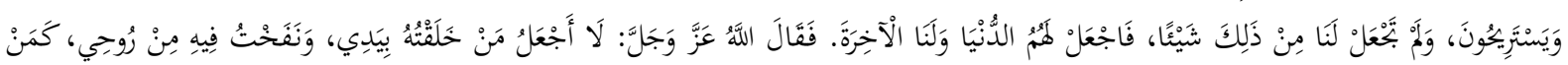

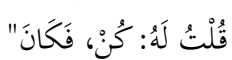

Ibnu Asakir telah meriwayatkan melalui jalur Muhammad ibnu Ayyub Ar-Razi, bahwa telah menceritakan kepada kami Al-Hasan ibnu Ali ibnu Khalaf As-Saidalani, telah menceritakan kepada kami Sulaiman ibnu Abdur Rahman, telah menceritakan kepadaku Usman ibnu Hisn ibnu Ubaidah ibnu Allaq; ia pernah mendengar Urwah ibnu Ruwayyim Al-Lakhami mengatakan bahwa ia pernah mendapat hadis ini dari Anas ibnu Malik, dari Rasulullah Shallallahu 'alaihi wa sallam yang telah bersabda: Sesungguhnya malaikat berkata, "Wahai Tuhan kami, Engkau telah menciptakan kami dan juga Bani Adam. tetapi Engkau jadikan mereka dapat makan, minum, berpakaian, dan mengawini wanita serta menaiki kendaraan. Mereka dapat tidur dan beristirahat, sedangkan Engkau tidak menjadikan sesuatu pun dari itu bagi kami. Maka berikanlah dunia kepada mereka dan berikanlah akhirat hanya untuk kami." Maka Allah Swt. berfirman, "Aku tidak akan menjadikan orang yang telah Aku ciptakan dengan tangan-Ku dan Aku tiupkan ke dalamnya sebagian dari roh (ciptaan)-Ku, seperti makhluk yang Aku ciptakan dengan mengatakan kepadanya, 'Jadilah kamu!' Maka terjadilah dia." Penjelasannya dapat juga di lihat dalam tafsir al-Sya'rawi yang ditulis oleh Muhammad Mutawalli atau terjemahannya halaman 330, jili 4 yang diterbitkan Duta Azahar Medan.

${ }^{20}$ Fakhruddin ar-Razi, Mafatih al-Ghaib, Juz 21 (Bairut: Darul Ihyaa Turas Arabi 1420 h), 372. 
kedua kakinya tegap lurus dan makan dengan menggunakan kedua tangannya serta diberikan akal, sementara makhluk lainnya makan langsung dengan mulutnya dan tidak di beri akal. Ayat di atas juga mengisyaratkan kemuliaan manusia atas malaikat dan jin.

Kedua, manusia dimuliakan dengan diberikan kemudahan untuk mengarungi darat dan lautan dengan berbagai moda angkutan. Angkutan darat model lama yang sudah dikenal adalah kuda, keledai, unta dan untuk lautanya adalah kapal, perahu. Namum seiring dengan perkembangan peradaban ditandai dengan kemajuan sains dan teknologi sebagaimana yang telah dijelaskan dan dijanjikan oleh Allah dalam surat al-Nahl/16:4-8 dan surat yasin/36:35 maka manusia dapat mengarungi daratan, lautan dan udara dengan transfortasi yang lebih maju, canggih, nyaman dan cepat. Ketiga,memberikan dan menyediakan bagi manusia makanan dan minuman dengan beraneka rasa baik secara alamiah maupun yang diolah dari kreasi manusia, sehat, segar dan memberikan banyak lagi kenikmatan lainnya.

Keempat, memberikan kelebihan dari makhluk Allah lainnya. Sepintas lalu point keempat ini seakan sama dengan point pertama, meskipun mirip tapi berbeda maknanya; yang pertama memakai takrim bermakna memuliakan yang lebih mengenalkan dasar-dasar keunggulan dan kemuliaan manusia yang melekat pada dirinya, sementara yang kempat memakai kata tafdhil yang mempunyai makna melebihkan yang dapat diartikan mengembangkan potensi-potensi yang sudah diberikan menjadi berdaya guna dan bermanfaat untuk sesama manusia terutama digunakan dalam rangka lebih banyak untuk mengenal Tuhannya dan mendekatkan diri kepadanya. ${ }^{21}$

d. Pemuliaan Martabat Manusia saat Meninggal

Kehormatan martabat manusia dalam Islam tidak sebatas ketika masih hidup di dunia dan beraktivitas di dalamnya dengan beraneka ragam kegiatan tetapi Islam telah menetapkan aturan untuk terus menghormati manusia ketika nyawanya telah merenggang atau sudah menjadi mayat. Pertama-tama yang harus dilakukan terhadap mayat adalah memandikan sebersih mungkin dengan memberinya wewangian $^{22}$ kemudian dikafankan dengan rapi sesuai aturan-aturan yang

\footnotetext{
${ }^{21}$ Abu al-Fadl Syihab al-Din Mahmud al-Alusi, Ruh al-Ma'ani, Juz. 15, (Beirut: Dar Ihya' alTuras al-'Arabi, t.h.), 118.

$$
\begin{aligned}
& \text { عَّحَ }
\end{aligned}
$$

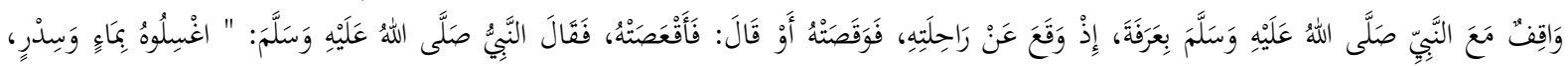

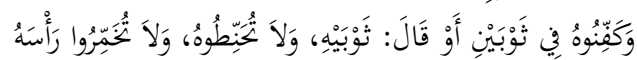

Ada seorang lelaki yang sedang wukuf di Arafah bersama Nabi shallallahu'alaihi wasallam. Tiba-tiba ia terjatuh dari hewan tunggangannya lalu meninggal. Maka Nabi shallallahu'alaihi wasallam bersabda: mandikanlah ia dengan air dan daun bidara.Dan kafanilah dia dengan dua lapis kain, jangan beri minyak wangi dan jangan tutup kepalanya. Karena Allah akan membangkitkannya di hari Kiamat dalam keadaan bertalbiyah. (Imam Bukhârî, Sahîh Bukharî, juz 3, hal. 17, bab Orang yang Meniggal di Arafah) dan yang senada:

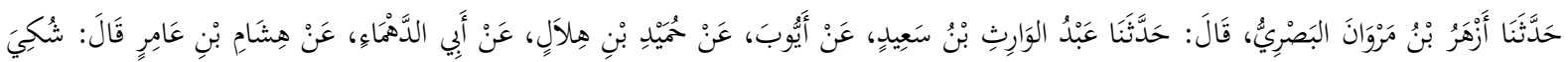

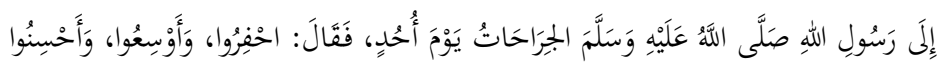


ditetapkan Islam. Dalam menangani mayat maka diharuskan diperlakukan dengan lembut dan sopan. Setelah selesai dari pemandian dan pengkafanan maka jenazah dishalatkan kemudian dikuburkan. Hal yang lebih penting sesuai pesan Nabi Shallallahu 'alaihi wa sallam adalah dilarangnya untuk mencela dan melontarkan kata-kata yang kurang pantas terhadap mayat sebagaimana hadisnya sebagai berikut,

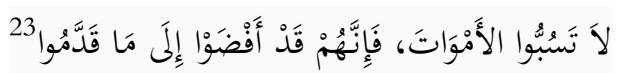

Janganlah kalian mencela mayat karena mereka telah menjumpai apa yang telah mereka kerjakan. (HR. Bukhari)

Dari penegasan larangan dari hadis di atas maka sejatinya seorang muslim harus dapat menahan lisannya untuk mengucapkan kata-kata yang tidak enak didengar apalagi sampai melontarkan kata-kata yang kasar terhadapa mayat. ${ }^{24}$ Islam mengajarkan adab dalam memperlakukan dan menghormati jenazah dari awal meninggalnya sampai dengan penguburan. Islam menganjurkan untuk mengantar jenazah ${ }^{25}$ sampai kepemakamannya baik dari janazah teman, kerabat, sahabat terutama sanak famili dan keluarga dekat. Hal ini termasuk dalam hadis yang dikatakan dari kewajiban seorang muslim terhadap saudaranya adalah memberi salam, mengunjungi orang sakit, menghadiri undangannya, mendoakan saudaranya ketika bersin dan terakhir mengantar jenazahnya sampai kekuburan. ${ }^{26}$

Secara umum pemuliaan martabat manusia ketika telah meninggal telah dijelaskan oleh Nabi secara rinci dan detil. Anjuran ini dapat dimulai dengan langkah pertama dengan melayat ketempat keluarga mayat yang berduka, menyampaikan duka cita dengan mendoakannya, kemudian memberikan nasehat agar bersabar dalam musibah, ${ }^{27}$ hadir dalam mensholatkan jenazah, mengantar

Nabi shallallahu'alaihi wasallam merintahkan menanangani mayat pada perangn Uhud "Galikan kuburan, perluas Kuburnya dan perlakukan dengan baik”( Imam Bukhârî, Sahîh Bukharî, juz 3, hal 265, bab Menguburkan Orang yang Mati Sahid)

${ }_{23}$ Imam Bukhârî, Sahîh Bukharî, juz 3, hal 265, bab Menguburkan Orang yang Mati Sahid

${ }^{24}$ Terdapat contoh teladan dalam suatu hadis yang dinukil dari kitab Ibnu al-Atsir (usud alGhabah) Inilah kisah teladan yang diceritakan oleh Ibnu al-Atsîr di dalam kitabnya Usud al-Ghabah : "Ketika Ikrimah bin Abu Jahal masuk Islam, banyak orang-orang yang berkata: 'Wah!, ini adalah anak musuh Allah, Abu Jahal'. Ucapan ini menyakiti hati 'Ikrimah karenanya dia mengadukan perihal tersebut kepada Rasulullah Shallallâhu 'alaihi wasallam, lantas beliau bersabda: "Janganlah kalian mencela ayahnya karena mencela orang yang sudah mati, akan menyakiti orang yang masih hidup (keluarganya).”

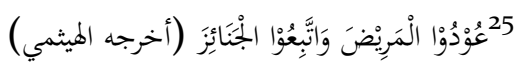

Jenguklah orang yang sakit dan ikutilah jenazah.

$$
\begin{aligned}
& 26
\end{aligned}
$$

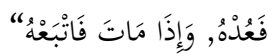

Hak seorang Muslim atas Muslim lainnya ada enam : bila engkau menjumpainya, maka ucapkanlah salam kepadanya, jika ia mengundangmu, maka sambutlah, bila meminta nasehat kepadamu, nasehatilah, jika ia bersin dan memuji Allâh, maka doakanlah, dan bila ia sakit, tengoklah, serta bila ia mati, iringilah jenazahnya". [HR. Muslim].

${ }^{27}$ Sebaik-baik ucapan takziyah adalah takziyah Rasulullah Shallallahu 'alaihi wa sallam kepada putrinya Zainab, ketika Zainab mengirim utusan kepada Nabi Shallallahu 'alaihi wa sallam memberitahukan bahwa bayinya meninggal dunia, maka Rasul bersabda: 
jenazah sampai ketempat peristirahatan terakhirnya dan mendoa'kannya. Tidak hanya sampai disitu, Nabi juga menganjurkan terhadap orang sekitar lingkungannya dan orang yang dilewati iringan jenazah atau melihatnya untuk menghormati jenazah tersebut sekalipun itu jenazah orang kafir atau Yahudi:

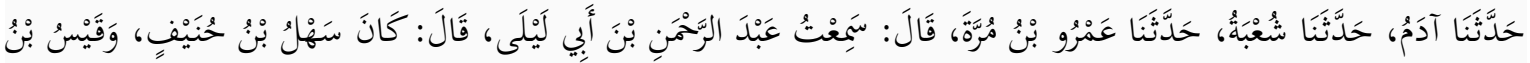

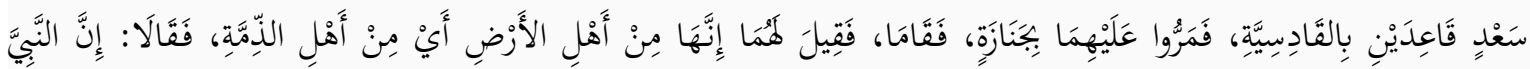

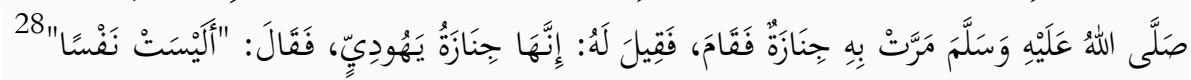

Dari Abdurahman bin Abi Laila berkata:Di Qadisiyah, (usai menempuh perjalanan jauh), Sahl bin Hanif dan Qais bin Saad duduk-duduk untuk beristirahat. Tiba-tiba ada sekelompok orang memikul keranda (jenazah). Keduanya berdiri. Orang lain yang melihatnya memberitahu keduanya bahwa jenazah tersebut adalah orang non muslim yang dilindungi, yaitu Yahudi. Lalu mereka mengatakan : "kami pernah bersama Nabi, lalu ada jenazah orang Yahudi lewat, Nabi berdiri. Kami katakan : "Nabi, itu kan jenazah orang Yahudi ?". Nabi mengatakan : نفأليست "Bukankah ia adalah jiwa (manusia)?” (HR. al-Bukhari)

Hadis di atas menjelaskan bahwa semua manusia harus dimuliakan dengan tidak memandang latar belakang dari mana berasal dan embel-embel yang dibawanya. Penghormatan kepada manusia murni semata-mata karena kemanusiaannya yang memiliki martabat dan kemuliaan yang melekat padanya tanpa pengecualian. Hak asasi manusia berada di atas segala-galanya.

e. Pemuliaan Martabat Manusia saat Penguburan

Setiap manusia pasti akan mati dan masuk keliang kubur. Menguburkan orang yang meninggal adalah fardu kifayah hukumnya, artinya bila sudah dilakukan sebagian orang maka gugurnya kewajibannya bagi yang lainnya. Oleh karena itu martabat manusia dalam Islam tetap terus akan terjaga dan terlindungi pada saat penguburan maupun sampai dengan penyediaan kuburan yang layak dan pantas bagi mayat sebagaimana telah dijelaskan oleh Nabi dalam hadisnya sebagai berikut,

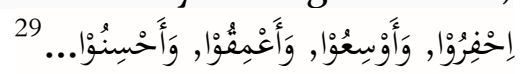

Galilah, lebarkanlah, perdalamlah, dan baguskanlah...

Lebih jauh lagi penghormatan martabat manusia termasuk juga menjaga adab terhadap kuburannya agar tidak dilakukan di atasnya hal-hal yang kurang pantas dan tidak patut. Dilarang melakukan hal-hal mungkar atau yang dilarang oleh agama.

f. Pemuliaan pada Kehidupan Abadi (yaumal Qiyamat)

Pemuliaan yang terakhir yang akan diterima oleh manusia adalah pada kehidupan yang abadi yaitu hari akhir. Dalam kehidupan tersebut manusia akan menerima kemuliaan berupa nikmat-nikmat yang tidak pernah dibayangkan

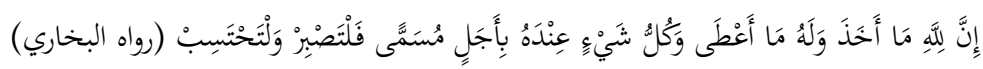

Sesungguhnya milik Allah untuk mengambilnya dan milikNya untuk diberikan, dan segala sesuatu disisiNya dengan ketentuan yang sudah ditetapkan waktunya. Maka, hendaknya engkau sabar dan ihtisab. (HR al-Bukhari])

${ }^{28}$ Al-Bukhari, Sahih al-Bukhari, juz 2, 85, Bab Orang yang berdiri karena jenazah Yahudi

${ }^{29}$ Imam Bukhârî, Sahîh Bukharî, juz 3, 265, bab Menguburkan Orang yang Mati Sahid 
dibenaknya sedikitpun, tidak pernah terlintas dihatinya, tidak pernah didengar dan dilihat olehnya, karena itulah sesungguhnya puncak kenikmatan yang akan dianugrahkan oleh Allah SWT kepada manusia sebagaimana disebutkan dalam hadis qudsi yang diriwayatkan oleh al-Bukhari sebagai berikut,

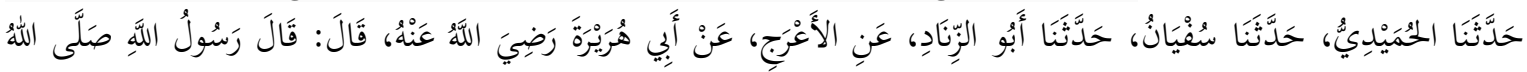

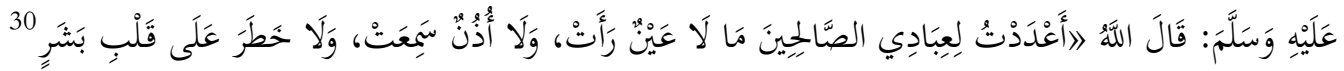

Dari Abu Hurairah ra bahwanya Rasulullah telah berkata, Allah SWT telah berfirman: aku telah siapkan untuk hamba-hamba-Ku yang shalih kenikmatan yang belum pernah dilihat sebelumnya dengan mata, belum pernah didengar sebelumnya dengan telinga dan tidak pernah sedikitpun terlintas dihati. (HR. al-Bukhari)

\section{HAM Dimensi Akidah, Syariat dan Akhlak}

Implementasi hak asasi manusia (HAM) tidak dapat dilepaskan dari aliran yang mewarnainya; teori dan pemikiran para penggagasnya. Penerapan HAM yang dipengaruhi dan diwarnai dari aliran yang disebutkan membawa dampak yang sangat besar pada sendi-sendi kehidupan manusia. Implementasi HAM yang beredar sekarang ini termasuk di Indonesia lebih banyak pengaruhi oleh pemikiran john Locke yang bersifat individualis atau disebut juga dengan paham liberal yang dipengaruhi paham materialistis. ${ }^{31}$ Aliran ini lebih mendahulukan kepentingan hal-hal yang bersifat kebendaan daripada nilai-nilai spiritual.

Kegagalan implementasi Hak Asasi Manusia (HAM) sekarang diyakini oleh banyak pengamat tidak terlepas dari pengaruh aliran tersebut yang menepikan nilainilai agama dari kehidupan dan aktivitas semua kegiatannya. Akibatnya adalah terabainya perawatan aspek rohani manusia yang kering dari asupan nilai spiritual. Manusia mengalami keterasingan dengan dirinya sendiri, mengalami keterpecahan kejiwaan karena lumpuhnya aspek spritual sebagai kebutuhan rohaninya. ${ }^{32}$ Paham materealistis mendorong untuk manusia melakukan konsumsi tanpa batas, sementara komsumsi akan mendorong untuk melakukan eksploitasi tanpa mengindahkan etika dan aturan yang ada bahkan lebih banyak menghalalkan segala untuk meraihnya yang pada akhirnya mengorbankan HAM dan lingkungan.

${ }^{30}$ Al-Bukhari, Sahih al-Bukhari, juz 4, hal 118, nomor hadis 3244, Bab Ciri-ciri sifat surga

${ }^{1}$ The Oxford English Dictionary memaknai materealisme dengan mendefinisikanya sebagai pengabdian pada keperluan dan keinginan yang berorientasi pada material, dengan mengabaikan halhal spiritual; cara opini hidup, atau kecenderungan yang sepenuhnya didasarkan pada perbedaan material. Symbol matrerialisme lima C : Credit Card, Car, Condominium, Club membership dan Cash. Ah Keng Kau dkk, "The lnfluence of Materialistic lnclination on Values, Life Satisfaction and Aspiration: An Empirican”, Analysis, Social Indicators Research, 49, 1ss. 3 (200o): 317-324.)

${ }^{2}$ Hal ini dapat dikatakan sebagai salah satu ancaman bagi keberlanjutan hidup manusia di masa depan, diakui oleh Myers tentang masalah kemanusiaan sebagai dampak kekeringan spiritual (materialisme) di Amerika Serikat dan ini menjadi peringatan bagi negara-negara lain:“... Rumah kami besar tapi tidak berguna, pendapatan tinggi dan moral rendah, mobil lebih baik dan bagus namun gangguan dan kemarahan lebih banyak ditemukan di jalan. Kami mampu, unggul dalam mencari nafkah tetapi lebih banyak gagal dalam menciptakan sebuah kehidupan. Kami merayakan kemakmuran tetapi kehilangan tujuan. Kami mengecap kebebasan kami tetapi mengharapkan relasi. Kemakmuran di dalam usia tapi kelaparan rohani mendera kami”. Myers, D. G, Social psychology (New York, NY: McGraw-Hill, 2008), 583-584. 


\section{Akidah}

\section{a. Peran Tauhid Sebagai Theologi Pembebasan}

Berbeda dengan apa yang dijelaskan di atas, implementasi konsep hak asasi manusia dalam Islam berdasarkan moral yang berbasiskan tauhid yang menjadi landasan dan rujukan terhadap semua lini aktivitasnya. Nilai-nilai tauhid merupakan salah satu faktor strategis yang menjadi kunci sukses hak asasi manusia dalam Islam untuk membebaskan manusia dari nilai-nilai lokal dan materialisme yang lebih banyak membawa bencana daripada kemaslahatan buat manusia.

Dalam perspektif Islam makna tauhid dapat diartikan secara luas sebagai manifestasi suatu keyakinan yang menjelaskan bahwa semua yang berada di dalam alam raya ini disediakan buat manusia untuk kesejahteraannya agar dapat memberikan kesenangan dalam kehidupan dan kebahagiaan bagi umat manusia. Seluruh sistem yang terdapat dalam raya ini baik dalam diamnya maupun dalam geraknya yang berjalan dengan keseimbangan dan harmonis secara teratur, bermuara kepada Allah SWT yang menunjukan kebesaran dan keagungan-Nya sebagai pencipta seluruh makhluk yang tidak membutuhkan kepada ciptaannya sedikitpun namun seluruh makhluk selalu bergantung dan membutuhkan-Nya. Segala sesuatu yang berkaitan dengan alur kehidupan yang berlangsung di dalam kehidupan manusia dengan seluruh aspek dan dimensinya yang disinggung oleh Al-Qur'an tidak terlepas dari mengesakan Allah SWT (tauhidullah) sebagai lini depan dalam dalam setap kegiatan dan aktivitasnya.

Tauhid memiliki kedudukan yang tinggi dan strategis sebagai pondasi dalam ajaran Islam yang sejalan dengan fitrah dan komitmet kemanusian sejak awal penciptaannya yang berfokus hanya untuk mengabdi, menyembah, bersyukur kepada Allah SWT. Lebih khusus lagi menjadikan Allah SWT hanya satu-satunya sebagai sumber nilai yang menjadi pegangan dan rujukan. Hal demikian pula yang menjadi semua misi Rasul untuk menyadarkan seluruh manusia sebagaimana tertuang dalam firman Allah SWT sebagai berikut,

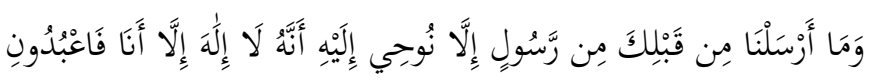

Dan Kami tidak mengutus seorang rasulpun sebelum kamu melainkan Kami wahyukan kepadanya: "Bahwasanya tidak ada Tuhan (yang hak) melainkan Aku, maka sembahlah olehmu sekalian akan Aku." (al-Ambiyâ/21:25)

Kalimat tauhid yang terdapat dalam La ilaaha illallah merupakan landasan dari suatu penegasan terhadap keesaan Allah SWT dan sebagai intinya serta sumber nilai. ${ }^{33}$ Nilai-nilai tauhid tersebut di atas dijabarkan dan dijelaskan oleh Al-Qur'an secara lengkap dan menyeluruh. Kemudian ditafsirkan oleh Rasul dengan penjelasan lebih rinci menjadi sebuah konsep yang menjadi panduan bagi umat manusia. Nilai-nilai tauhid di atas bermetamorfosis menjadi gerakan pembebas yang menjauhkan manusia dari nilai-nilai yang merusaknya (HAM). Tauhid menjadi simbol pembebas yang membebaskan manusia dari perbudakan dan menyembah sesama manusia kepada pengabdiaan hanya semata kepada Allah SWT. ${ }^{34}$

\footnotetext{
33 Ismail Raji al-Faruqi, Tauhid (Bandung: Pustaka, 1988), 16.

${ }^{34}$ Wan Mohd Nor Wan Daud, Filsafat dan Praktik Pendidikan Islam Syed Muhammad Naquib alAttas, terj. hal. 174)
} 
Kebebasan dan kemerdekaan akan menjadi lebih cepat diraih dari setiap individu dalam realitas kehidupannya manakala nilai-nilai tauhid menjadi keyakinan dan pegangan dalam hidupannya. Di dalam naungan tauhid seseorang akan sadar bahwa kebebasan dan kemerdekaan merupakan haknya dan menyadari tidak ada perbedaan antara manusia satu dengan yang lainnya apapun bentuknya yang disebabkan oleh perbedaan latar belakangnya. Manusia tetap manusia tanpa ada perbedaan sedikitpun. Perspektif tauhid memiliki dan memegang peranan penting dalam mengembalikan manusia untuk menyadari kedudukannya dan menjadi arus utama dalam membentuk sikap dan karakrter manusia dalam bersikap dan bertindak.

Pelanggaran demi pelanggaran yang terjadi terus menerus akhir-akhir ini terhadap hak asasi manusia (HAM) lebih banyak diakibatkan oleh kekosongan nilainilai tauhid dari hati manusia sebagai sebuah pegangan nilainya. Manusia hanya berpikir terhadap kepentingannya sendiri tanpa mau berbagi dan memandang orang lain. Arus egoisme yang lebih mengutamakan kehidupannya terlebih tanpa peduli dengan sekelilingnya akan membawa implikasi berupa kerusakan ditengah-tengah manusia.

Kehadiran nilai tauhid sangat penting sekali terutama untuk memperbaiki pandangan manusia yang keliru terhadap kehidupannya dan membawa nilai-nilai spiritual bermuatan positif ke dalam hati manusia agar dapat mengendalikan emosi dan hatinya. Emosi dan hati yang diwarnai oleh nilai spiritual akan lebih dan teduh serta membawa dampak positif dalam segala aktivitas dan kegiatannya baik terhadap diri sendiri, keluarga, masyarakat dan lingkunganya.

Keberhasilan nilai tauhid di awal munculnya pertama kali adalah berhasil membebaskan masyarakat arab jahiliyyah yang terbelakang dan menjauhkan mereka dari perbuatan yang menindas hak asasi manusia (HAM): saling bunuh, menindas sesama mereka, perang antara suku, perbudakan, perendahan terhadap martabat perempuan, perbudakan dan lain sebagainya. Tidak sebatas itu tapi menjadikan masyarakat arab jahiliyyah lebih maju, berbudaya dan menjadikan mereka masyarakat madani. Dialog antara sahabat Ja'far ibn Abi Thalib dengan Najasyi, Raja Habasyah (Ethopia) dalam hadis berikut ini akan menjelaskan hal-hal yang disinggung di atas:

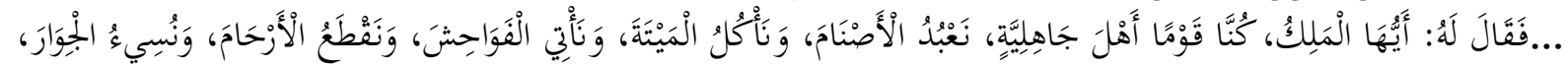

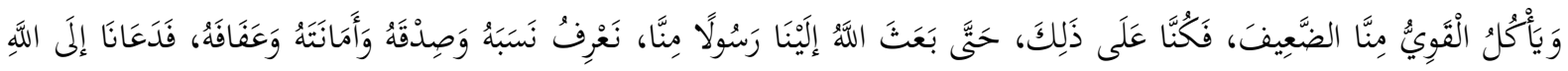

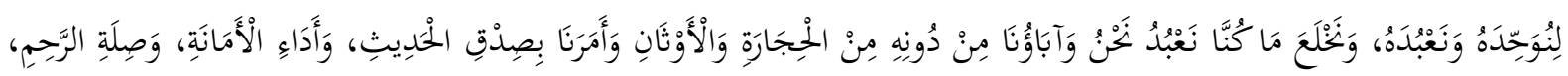

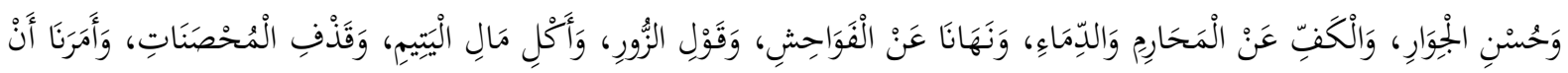

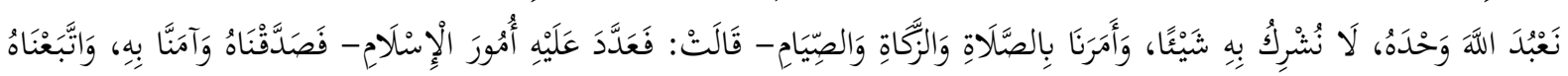

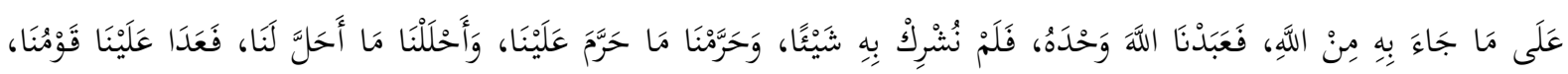

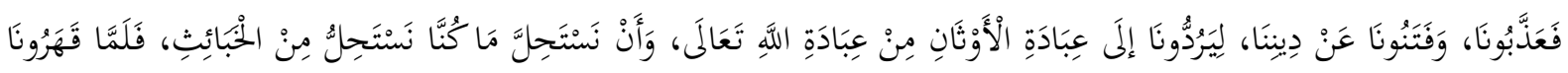

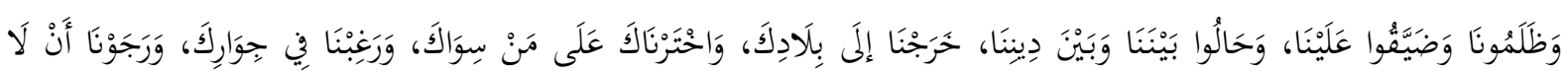

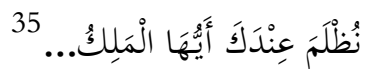

${ }^{35}$ Ibn Hisyam , al-Sîrah al-Nabawiyyah, Kairo: al-Maktab al-Sâqafi, t.th, juz 1, hal. 192.

67 | al-ðurhan: Kajian Ilmu dan Pengembangan Budaya Al-Qur'an, Vol. 20, No. 1, Juni 2020: 50-79. 
Paduka Raja, dahulunya kami adalah termasuk bagian dari golongan orang-orang terbelakang (jahiliyyah). Kami menghamba dan menyembah pada berhala, mengambil bangkai sebagai makanan, mengerjakan pekerjaan dan perbuatan keji, memutuskan ikatan tali kekeluargaan, senantiasa melakukan perbuatan buruk terhadap tetangga, dan orang-orang kuat di antara kami 'menindas' orang-orang yang lemah. Begitulah keadaan kami dulunya sampai Allah mengutus seorang Rasul kepada kami dari golongan dan kalangan kami sendiri yang kami mengetahui garis keturunannya, kami ketahui kejujuran, keamanahan dan kehormatanya. Beliau menyeru kepada kami agar mentauhidkan Allah SWT dan hanya menyembah kepada-Nya semata, menjauhi sesembahan selain Allah, yang selama ini telah dilakukan oleh kami dan juga nenek moyang kami, seperti patung, batu dan berhala-berhala lainnya. Beliau mengajak kami agar senantiasa berkata jujur, menunaikan amanah, menjaga dan menjalin ikatan tali kekeluargaan, berbuat hal-hal yang baik terhadap tetangga, menjauhi urusan-urusan yang dilarang atau diharamkan dan tidak menumpahkan darah. Melarang kami dari melakukan perbuatan-perbuatan yang keji, berbohong, berdusta, mengambil hartaharta anak yatim dan melemparkan tuduhan terhadap wanita yang baik-baik. Beliau mengajak dan menyeru kepada kami hanya melakukan penyembahan hanya terhadap Allah semata dan tidak mempersekutukannya dengan sesuatu apa pun....

\section{b. Peran Tauhid dalam Kebebasan Manusia}

Kebebasaan merupakan kebutuhan setiap manusia agar dapat hidup layak sebagai manusia. Tanpa kebebasan maka eksistensi manusia akan terganggu dan mengalami distorsi. Kebebasan inilah yang digaungkan dan diteriakan awal-awal maraknya revolusi di Barat karena mereka penat dan letih dalam kehidupannya karena terkurung tanpa dapat menghirup udara kebebasan. Teori kodrati John Locke pada intinya adalah meneriakkan kebebasan bagi masyarakat Barat yang hilang dan tertindas dalam semua aspek kehidupannya.

Islam sejak awal datangnya telah meletakan dasar-dasar dan konsep kebebasan yang terukur dan dapat diterapkan dalam segala aspek kehidupan dengan mudah dan sederhana. Konsep kebebasan yang yang berbasiskan tauhid sebagai sebuah keyakinan berhasil menghantar manusia untuk menghirup udara segar kebebasan tanpa ada rasa takut sedikitpun termasuk kelas sosial yang paling bawah (kelas budak) baik dari komunitas laki-laki maupun komunitas perempuan sebagaimana diterangkan dalam hadis berikut ini,

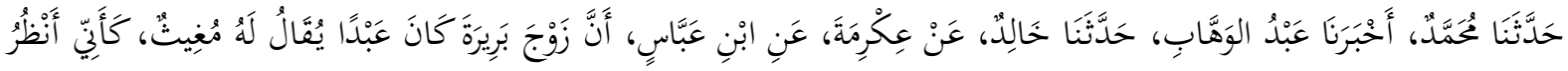

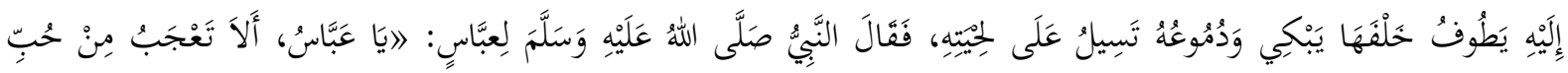

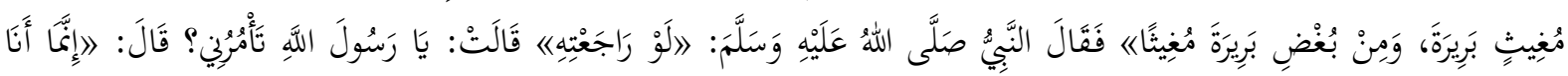

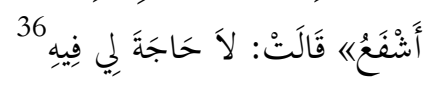

Dari 'Ikrimah, dari Ibnu 'Abbas, ia berkata, bahwasanya suami Barirah merupakan seorang budak yang bernama Mughits. Aku ingat bagaimana Mughits terus mengikuti Barîrah ke manapun ia pergi sambil menangis sampai-sampai membasahi jenggutnya (karena mengharapkan cintanya Barirah,). Nabi shallallahu 'alaihi wa sallam berkata

${ }^{36}$ Muhammad Ibrahim Salim, Perempuan-Perempuan Mulia di Sekitar Rasullullah shallallâhu 'alaihi wasallam (Jakarta: Gema Insani Press 2002), 57. 
kepada pamannya, Abbas, "Wahai Abbas, tidakkah engkau merasa heran sungguh besar rasa cintanya Mughîts terhadap Barîrah tetapi betapa besar pula rasa kebencian Barîrah kepada Mughîts."Nabi shallallahu 'alaihi wa sallam berkata kepada Barîrah, "seandainya engkau mau kembali lagi kepada Mughîts?!" Barirah menjawab, "Wahai Rasulullah, apakah engkau memerintahkanku?" Nabi shallallahu 'alaihi wa salalm berkata, "Aku hanya ingin menjadi perantara (syafi')." Barîrah brkata, "Aku tidak membutuhkannya lagi" (HR. Bukhari)

Dialog dalam hadis di atas menunjukan kesantunan dan kesopanan seorang Nabi sebagai pemimpin yang mengajarkan dan menghormati hak seorang budak perempuan untuk memberi ruang dialog dan berkomunikasi tanpa tekanan sehingga menghilangkan perasaan takut dan berani berbicara dengan bebas terhadap seorang Pemimpin (Nabi Shallallahu 'alaihi wa sallam ) dengan tegas dan lugas. Keberanian dan kebebasan yang didapatkan oleh seorang budak perempuan tersebut di atas memberikan indikasi yang berkaitan dengan suasana dan lingkungan masyarakat arab yang telah tercerahkan oleh nilai-nilai tauhid yang bersumberkan dari Al-Qur'an. Nilai-nilai tauhid menjadi konsep baru dalam kehidupan mereka, baik dalam seluruh aspek hubungan kehidupan sosial yang dibangun sesama mereka maupun hubungan vertikal yang dibangun antara mereka dengan Allah SWT. Mereka bangga dengan Islam dan senang menjadikannya sebagai jalan hidup mereka karena tauhid telah membebaskan mereka dari kebodohan dan pelanggaran HAM sebagaimana perkataan sayyidina Umar:

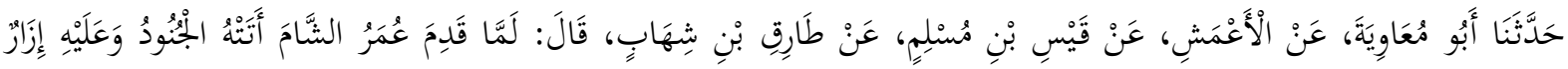

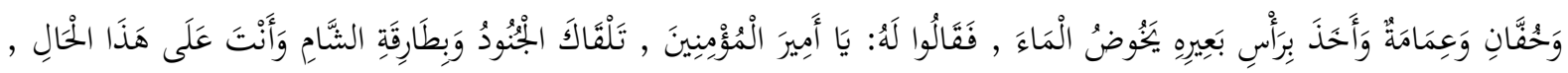

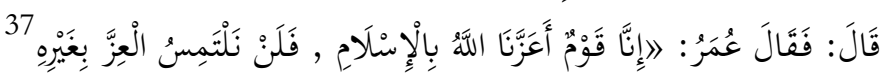

...Maka berkata 'Umar, "Sesungguhnya kami adalah suatu kaum yang telah dimuliakan oleh Allah dengan Islam, maka kami tidak akan pernah mencari lagi kemuliaan dengan selain Islam ".

\section{Syariat}

Untuk melindungi hak asasi manusia dalam realitas kehidupan diperlukan undang-undang yang harus menjadi pedoman dan sebagai bentuk produk hukum yang memuat sanksi-sanksi bagi yang melanggarnya. Kehidupan dengan seluruh dinamikanya dan bermacam aspek yang saling berhubungan satu dengan yang lainnya dari aspek hubungan dengan individu, keluarga, masyarakat dengan beragam bentuk aktivitasnya, semuanya membutuhkan hukum agar semuanya berjalan lancar dan harmonis. Sesungguhnya semua hukum yang ada didunia ini apapun bentuknya yang telah dibangun bukan untuk kepentingan hukum tapi demi kepentingan manusia itu sendiri tak terkecuali hukum Islam.

\section{a. HAM Dalam Naungan Syariat}

Keadilan menjadi tema sentral yang berkaitan dengan HAM. Keluhan dan aduan yang masuk ke Komisi Lembaga Hak Asasi Manusia (KomnasHAM) lebih banyak

${ }^{37}$ Ibnu Asakir, sejarah Damaskus, (Bairut: Darul Fikr, 1995), juz 5, hal 44. 
porsinya yang berkaitan dengan keadilan yang belum terwujud dan diraih masyarakat. Hukum positif gagap dan gugup dalam mensikapi keadilan dan menjadikannya dapat terwujud di tengah-tengah masyarakat, karena prinsip keadilan sesungguhnya harus hadir dalam kehidupan berbangsa dan bernegara sebagai tuntutan yang diamanatkan dalam Pembukaan Undang-Undang 1945. Oleh Karena itu menempatkan keadilan sebagai prinsip penting untuk mencapai tujuan bernegara dalam semua aspek yang melingkupinya. ${ }^{38}$

Konsep dasar hukum positif sangat jauh berbeda baik dari segi konsepnya maupun dari aspek semangat yang menjadi basisnya. Salah satu konsep dasar dan pondasi yang kokoh yang bersifat universal, dapat dijadikan contoh oleh hukum positif adalah sebagaimana yang tertuang dalam surat al-Nisa'/4:135:

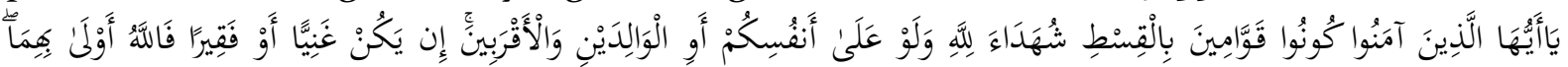

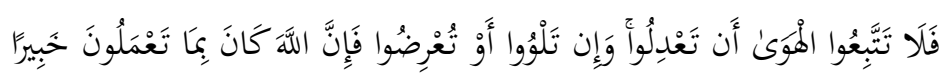

Wahai orang-orang yang beriman, jadilah kamu orang yang benar-benar penegak keadilan, menjadi saksi karena Allah biarpun terhadap dirimu sendiri atau ibu bapa dan kaum kerabatmu. Jika ia kaya ataupun miskin, maka Allah lebih tahu kemaslahatannya. Maka janganlah kamu mengikuti hawa nafsu karena ingin menyimpang dari kebenaran. Dan jika kamu memutar balikkan (kata-kata) atau enggan menjadi saksi, maka sesungguhnya Allah adalah Maha Mengetahui segala apa yang kamu kerjakan.

Ayat di atas menjelaskan bahwa sejatinya seorang muslim tidak hanya berteori tentang keadilan namun memerintahkan mereka harus menerapkannya dalam seluruh aspek kehidupan mereka, dalam posisi apapun kedudukannya. Penerapan keadilan tidak hanya tertuju pada orang lain tapi menyangkut juga terhadap diri sendiri, kedua orang tua dan kerabat dekat atau jauh, terhadap orang miskin maupun kaya. Pesan lain yang ditekankan dalam tersebut adalah dilarangnya pemutar balikan fakta dan mempermainkan hukum dengan mengikuti hawa nafsu. Hak Asasi Manusia akan dapat terrealisasi dalam realitas kehidupan dengan maksimal untuk menjaga dan memlindunginya manakala ayat di atas menjadi payung dalam aplikasinya.

\section{b. Hukum Islam Bersifat Kemanusiaan}

Hukum Islam sangat fleksibel dan dapat beradabtasi dengan perkembangan zaman maupun dalam kondisi tertentu. Dari tinjauan kaedah hukum fikih yang ada maka perubahan waktu, kondisi, zaman sudah dapat di antisipasi jauh-jauh sebelumnya. Memang demikianlah seharusnya. Perubahan kondisi manusia secara individual dan zaman secara umum merupakan keharusan dan keniscayaan. Oleh karena itu sebagai syariat yang berasal dari Allah tentunya telah memberikan isyaratisyarat tersebut yang dapat dipahami dari kandungan yang termuat yang di dalamnya. Dengan demikian syariat atau hukum fikihnya senantiasa berkembang dan dapat menyesuaikan dirinya dengan perkembangan zaman karena memiliki faktor-faktor dan dimensi-dimensi yang terkandung dalam konsepnya yang dapat menghindarinya

${ }^{8}$ Fancis Fukuyama, Memperkuat Negara, Tata Pemerintahan dan Tata Dunia Abad 21, (Jakarta: Gramedia Pustaka Utama 2004), hal. 10. 
dari stagnasi dan finalisasi, bahkan selalu siap untuk menghadapi segala bentuk perubahan dan menerima pembaharuan, dan dapat dengan mudah diaplikasikan.

Hal demikian sebagaimana diungkapkan oleh Imam Ibnu al-Qayyim bahwa kehadiran syariat Islam pada hakekatnya adalah untuk kemaslahatan manusia dan mendatangkan ketenangan, dan kesejahteraan. Sesungguhnya syariat Islam yang dibangun berlandasan hukum dan kemaslahatan untuk manusia adalah untuk menegakan keadilan dan menebar kasih sayang di tengah-tengah kehidupan manusia. Jika terdapat suatu bentuk pendapat dan ajaran yang dihubungkan dengan permasalahan agama tetapi tidak mendatangkan keadilan, kasih sayang dan hikmah, maka dapat dipastikan hal demikian bukan berasal dari agama. ${ }^{39}$ Sejatinya syariat harus menampilkan wajah dari keadilan Allah dan menifestasi dari hikmahnya untuk manusia, dan sebagai rahmat terhadap seluruh makhluknya di muka bumi.

Dalam pandangan Yusuf al-Qardawi, bahwasanya syariat Islam dapat beradaptasi dengan perubahan dan mau menerimanya serta dapat menerima pembaharuanpembaharuan yang datang berdasarkan landasan yang kokoh, antara lain memiliki orisinilitas (al-asâlah). Selain itu hukum Islam mempunyai perbedaan-perbedaan yang jelas dengan segala produk hukum yang ada di muka bumi dan undang-undangnya dibuat oleh pemikiran manusia. Perbedaan tersebut meliputi seluruh aspeknya baik tujuan, maksud dan landasannya serta asal sumbernya sebagai pegangan dan rujukan. Disamping itu, hukum Islam dapat mengalami perombakan (taghyîr) melalui perubahan dan berpeluang untuk menerima pembaharuan lainnya ((tajdîd). ${ }^{40}$

Hukum Islam ditinjau dari perspektif fikih ciri-cirinya lebih bernuansa insaniyah karena keberadaan manusia beserta hakekatnya dapat diakui dan diakomodir secara luas dan menyeluruh, meliputi: jiwa, akal, hati dan perasaanya, melindungi martabat manusia baik ketika di dalam kehidupan dunianya maupun setelah menjadi mayat, memberikan perlindungan kepada janin yang masih berada di dalam kandungan dan menjaga harta serta hak-hak yang dimiliki oleh manusia yang lebih di kenal dengan sebutan Huqûq al-Insân (HAM).

Hal demikian menurut Yusuf al-Qardhawi dapat dibuktikan dengan penghormatan oleh Rasul dengan berdiri ketika jenazah orang Yahudi lewat di hadapannya sebagaimana terdapat dalam hadis yang diriwayat oleh al-Bukhari yang telah disinggung di atas. Hal tersebut menunjukan bahwa hukum Islam benar-benar memperhatikan sisi kemanusiaan dan memuliakan kedudukan manusia, dan memberikan contoh kepada seluruh manusia untuk saling menghormati meskipun terhadap mereka yang berbeda keyakinan bahkan sekalipun telah menjadi mayat. ${ }^{41}$ Penjelasan di atas bukan tanpa alasan atau ungkapan yang berlebihan; bahwa hampir seluruh hukum fikih dalam Islam semuanya bertujuan untuk kebahagian dan kesejahteraaan manusia. Hal demikian dapat dilihat bahwa pembahasan yang berkaitan dengan urusan ubudiyah dalam tinjauan fikih Islam hanya sekitar seperempatnya. Sisanya lebih banyak membahas hal-hal yang mempunyai kaitan dengan urusan kemanusiaan, seperti hukum keluarga (ahwäl al-Shakhsîyah), hukum pidana (jinayah), sanksi ('uqubah), mu'amalah (mencakup bisnis, transaksi,

\footnotetext{
${ }^{39}$ Khadijah al-Nabrawi, Mausuah Huquq al-Insan fi al-Islam (Mesir: Dar al-Salam, 2006), 289.

40 Yusuf al-Qardâwî, al-Fiqh al-Islâmî, 9.

${ }^{41}$ Yusuf al-Qardâwî, al-Fiqh al-Islâmî, 9-10.
} 
perdagangan yaitu sewa, gadai, jual-beli dan selain sebagainya), dan pernikahan, seluruhnya itu merupakan ikatan personal yang menyangkut hubungan seseorang dengan orang lain. ${ }^{42}$

Sesungguhnya hukum fikih yang bersifat ubudiyah jika lebih teliti lagi pembahasannya juga kembali untuk kepentingan yang menyangkut kemanusiaan. Sebagai contohnya adalah zakat, apabila batas harta seseorang muslim telah mencapai takarannya atau batas yang telah ditentukan (nisab) maka diwajibkan mengeluarkan jumlah tertentu untuk diberikan kepada kelas sosial atau golongan yang membutuhkannya (al-mustahiqqîn) sebagai ibadah (ketaatan) terhadap Allah SWT. Shalatpun yang diwajibkan dilakukan oleh seorang muslim dalam lima kali sehari, fungsinya tidak terlepas dari dimensi kemanusiaan yang tinggi yaitu untuk mencegah seseorang membuat kerusakan (mungkar) dan menghindarkan seseorang melakukan perbuatan yang merugikan orang (melanggar HAM). ${ }^{43}$

Pembahasan hak asasi manusia dalam perspektif Islam lebih banyak berkaitan dengan lima hal pokok (al-dlaruriyat al-khamsah atau yang disebut juga al-huquq alinsaniyah fi al-islam) yang menjadi dasar dari HAM itu sendiri yaitu menjaga agama (hifdzu al-din), menjaga jiwa (hifdzu al-nafs), menjaga akal (hifdzu al-'aql), menjaga harta (hifdzu al-mâl), menjaga keturunan (hifdzu al-nasl). Kelima hal tersebut merupakan dasar dari HAM yang harus dijaga dan dilindungi keberadaannya. Dengan lima hal tersebut manusia akan hidup dengan sempurna dan eksistensinya sebagai manusia akan diakui.

Konsep al-dlaruriyat al-khamsah atau yang disebut juga al-huquq al-insaniyah $\mathrm{fi}$ al-islam dalam aplikasinya dilapisi oleh tiga hal yang selalu mengiringnya sebagaimana diterangkan di dalam fikih; pertama, hak pokok atau dharurat yang merupakan kebutuhan primer yang harus dipenuhi oleh manusia, karena konsekwensi tidak dipenuhinya kebutuhan primer atau pokok maka kehidupan manusia terancam bahkan eksistensinya sebagai manusia akan pudar. Kedua, adalah kebutuhan sekunder atau ta'ziat yang merupakan kebutuhan dibawa kebutuhan primer dimana jika tidak dipenuhi tidak membahayakannya. Ketiga, kebutuhan komplementar (tahsinat) dimana posisinya hanya sebagai pelengkap dari kebutuhan di atas. ${ }^{44}$

\section{Akhlak}

Dalam teori kebutuhannya Abraham Maslow meletakan kebutuhan keamanan ${ }^{45}$ pada peringkat kedua setelah kebutuhan pokok, meskipun sebenarnya antara keduanya saling kait mengait dan punya hubungan yang kuat serta setara; kebutuhan

${ }^{42}$ al-Qardâwî, Karakteristik Islam; Kajian Analitik, Terj. Rafi` Munawwar (Surabaya: Risalah Gusti, 1995), 75 .

${ }^{43}$ Hal demikian sesuai dengan Al-Qur'an surah al-'Ankabût ayat 29 yang berbunyi:

$$
\text { وأقم الصلوة إن الصلوة تنهى عن الفحشاء والمنكر }
$$

"Sesungguhnya shalat itu mencegah dari (perbuatan- perbuatan) keji dan mungkar." Dikuatkan pula dengan hadis Nabi yang berbunyi:

$$
\text { من صلى صلاة لم تنهه عن الفحشاء والمنكر لم يزدم بها من الله إلا بعدا }
$$

"Barang siapa melaksanakan shalat namun shalatnya tidak mampu mencegah dari perbuatan keji dan munkar maka tidaklah bertambah baginya kecuali jauhnya dari Allah."

${ }^{44}$ Masdar F. Masudi, "Hak Asasi Manusia dalam Islam", dalam E. Shobirin Nadj dan Naning Mardiiah (Ed.), Desiminasi HAM Perspektif dan Aksi (Jakarta: CESDA LP3ES, 20oo), 66.

${ }^{45}$ Abraham Maslow , A Theory of Human Motivation, di Psychological Review 1943. 
pokok akan terganggu tanpa adanya keamanan dan keamanan akan terganggu tanpa tersedianya kebutuhan pokok. Oleh karena itu Al-Qur'an selalu mengaitkan antara keduanya dalam beberapa ayatnya. Agar keduanya terwujud maka perlunyan terciptanya kedamaian dan perdamaian dalam kehidupan manusia supaya Hak Asasi Manusia dalam seluruh aspeknya tidak terganggu dan dilanggar.

\section{a. Kebutuhan HAM Terhadap Perdamaian dan Kedamaian}

Hak Asasi Manusia akan terlindungi dan terjaga dari segala gangguan apabila tercipta suasana perdamaian, kedamaian, ketenangan dan keamanan ditengah-tengah masyarakat. Wahiduddin Khan menjelaskan, kedamaian merupakan kebutuhan dasar yang dibutuhkan manusia; kehidupan manusia akan berjalan normal dan hidup apabila kedamaian hadir ditengah-tengah kehidupan mereka, tetapi sebaliknya jika kedamaian pudar dan redup dari kehidupan mereka, maka manusia (HAM) akan menghadapi problem dan kehancuran. ${ }^{46}$ Hal demikian tidak hanya terjadi dalam kehidupan manusia dalam keadaan tanpa perang, konflik ataupun kekerasan, tetapi diindikasikan juga absennya kekerasan struktural dan terwujudnya kesejahteraan dan keadilan sosial serta didukung oleh suasana yang harmonis.

Hal ini disadari oleh Nabi Muhammad SAW yang telah meletakan suatu konsep dasar yang jelas dan sederhana yang mudah untuk dipahami dan dapat dengan mudah dilaksanakan dari tingkatan semua level dan kelas dimasyarakat secara cepat, tepat dan tidak bertele-tele tapi langsung mengena pada inti permasalahannya. Hal ini termuat dalam suatu perkataan Nabi ketika mau masuk kota Madinah untuk membangun masyarakat madani, masyarakat berkemajuan yang penuh dengan keadilan dan jauh dari pelanggaran HAM:

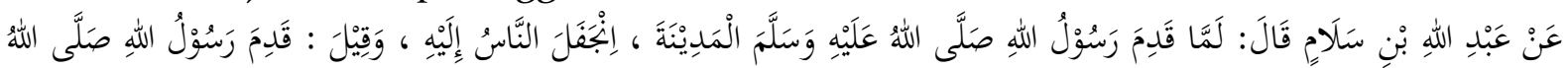

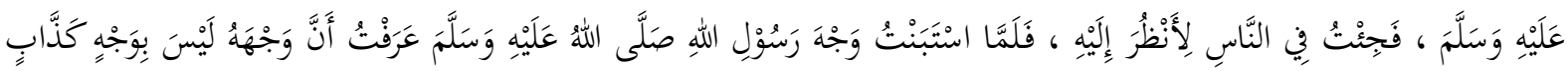

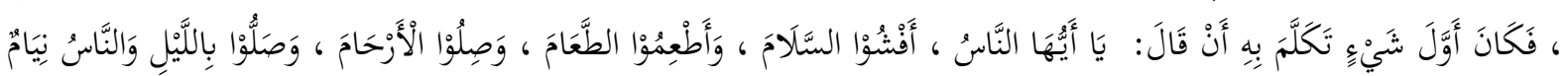

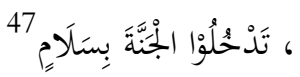

Dari 'Abdullah bin Salâm, ia berkata: "Pada saat Rasûlullâh Shallallahu 'alaihi wa sallam datang ke Madinah, orang-orang segera berlari menuju Rasul Shallallahu 'alaihi wa sallam (karena ingin melihatnya). Ada yang mengatakan: Rasûlullâh Shallallahu 'alaihi wa sallam telah tiba, kemudian aku menghampirinya ditengah-tengah kerumunan orang banyak hanya untuk melihatnya. Ketika aku melihat wajah Rasûlullâh Shallallahu 'alaihi wa sallam, aku mengetahui bahwa raut wajahnya bukanlah menunjukan wajah seorang pembohong. Dan sesuatu yang pertama kali beliau katakan adalah, 'Wahai sekalian manusia, sebarkanlah salam, berikan makan, sambunglah silaturrahim, dirikan shalat di tengah malam ketika orang-orang lagi tertidur, niscaya kalian akan masuk ke dalam Surga dengan sejahtera."

Komponen dasar untuk menegakkan dan melindungi hak asasi manusia disebutkan secara jelas dalam tersebut di atas. Hal tersebut juga sejalan sebagai sebuah prasyarat untuk membangun sebuah peradaban manusia atau masyarakat

\footnotetext{
${ }^{46}$ Maulana Wahiduddin Khan, The Ideology of Peace, (New Delhi: Goodword Book, 2010), hal. 12.

${ }^{47}$ Al-Baihaqi, Kitab adab, juz 1, (Mekkah: Maktabah Dâr al-Bâz, 1994), 31, no. hadis 927, bab Memberi Makanan dan Minuman.
} 
madani agar kehidupan sosial masyarakat penuh dengan damai, tenang dan tentram dimana hak asasi manusia terjamin di dalamnya tanpa ada kekhawatiran untuk dilanggar.

\section{b. Melindungi dan Menjaga HAM dengan Akhlak Karimah}

Ada empat komponen pokok untuk menegakan HAM yang digagas oleh Nabi Shallallahu 'alaihi wa sallam dalam hadis di atas sekaligus merupakan konsep dasar untuk mencapai masyarakat yang berkeadilan dan menjunjung tinggi nilai-nilai HAM.

1) Tebarkan Perdamaian (Salam)

Dalam hadis di atas dianjurkan pembumian perdamaian untuk menciptakan kedamaian melalui penebaran salam (perdamaian) sebagai langkah awal untuk membangun suasana kehidupan yang penuh dengan kedamaian dan ketenangan. Oleh karena itu dalam hadis lain dijelaskan aplikasi pembumian dan penebaran salam sebagai berikut,

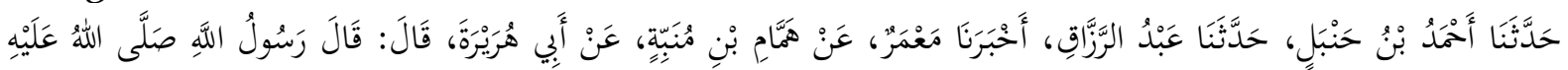

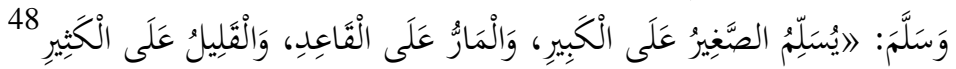

Dari Abu Hurairah bahwasanya Nabi shallallahu 'alaihi wa sallam bersabda: hendaklah yang kecil memberi salam kepada yang besar, yang berjalan memberi salam kepada yang duduk, yang sedikit memberi salam kepada yang banyak. (HR. al-Bukhâri)

Etika dan moralitas dalam perilaku akhlak mulia adalah dengan memposisikan agama yang tampil dengan fungsi profetiknya dengan menebarkan salam (perdamaian); minimal bisa dimulai dengan mengucapkan salam perdamaian agar dapat mengisi ruang atmosfir kehidupan dengan kalimat tayyibah yaitu salam perdamaian yang pada gilirannya nanti menuntut dan mengikat manusia untuk mewujudkannya di tengah-tengah kehidupan mereka. Inilah yang dikehendaki oleh hadis Nabi shallallahu 'alaihi wa sallam di atas untuk melatih manusia agar selalu mengisi memori mereka dan mengingatkannya tentang pentingnya perdamaian agar terus hadir dalam hati dan pikiran, agar terus tengiang-ngiang dalam telinga dan hati mereka, artinya raga dan phisik mereka senantiasa di penuhi dengan kepedulian terhadap perdamaian.

2). Kepedulian Sosial

Kepedulian sosial adalah sebuah tindakan yang ingin memberi bantuan kepada sesama dan masyarakat. ${ }^{49}$ Indikator karakter kepedulian sosial menurut Samani \& Haryanto di antaranya adalah: pertama, memperlakukan orang lain dengan sopan; kedua toleran terhadap perbedaan; ketiga, mampu bekerja sama; keempat, mau terlibat dalam kegiatan masyarakat; kelima, tidak ada terselip keinginan untuk meraih

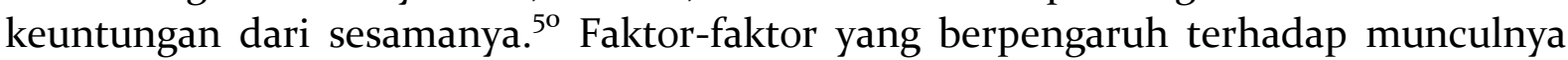
stabilitas dan instabilitas sosial dalam hubungan sosial salah satunya adalah stratifikasi sosial. Stratifikasi sosial pada suatu sisi, dapat menjadi pendorong terciptanya

\footnotetext{
${ }^{48}$ Sahîh al-Bukhârî, juz 8, hal. 52, no. hadis 6231, bab Memberi Salam Orang yang Sedikit Kepada Orang yang Banyak.

${ }^{49}$ Sudrajat dkk,. Pendidikan Karakter dalam Perspektif Teori dan Praktik (Yogyakarta: UNY Press, 2011), 170

${ }^{5}$ Muchlas Samani \& Haryanto, Pendidikan Karakter Konsep dan Model (Bandung: Rosdakarya, 2011), 51 .
}

al-\$urhan: Kajian Ilmu dan Pengembangan Budaya Al-Qur'an, Vol. 20, no.1, Juni, 2020: 50-79| 74 
stabilitas sosial, karena manusia menyadari adanya ketergantungan antara manusia satu dengan manusia lain, namun dari aspek lain menyimpan potensi terhadap instabilitas sebagai konsekuensi dari potensi yang berbeda yang dimiliki oleh masingmasing individu atau kelompok..$^{51}$

Oleh karena itu perlu di bangun kepedulian dan solidaritas sosial sebagai perekat sosial antar kelas-kelas sosial yang ada di masyarakat. Ajaran Islam yang terdapat AlQur'an dan hadis Nabi shallallahu'alaihi wa sallam, sebagai petunjuk bagi ummmat manusia hampir semuanya berkaitan dengan membina dan menjaga keharmonisan hubungan antar kelas-kelas sosial yang ada dimasyarakat termasuk penerapan hukumhukumnya.

Salah satunya firman Allah dalam surah al-Nisa'/4:36 dapat menerangkan tentang perlunya perekat sosial berupa berbuat ihsan (mengulurkan bantuan) terhadap sesama manusia sebagai berikut,

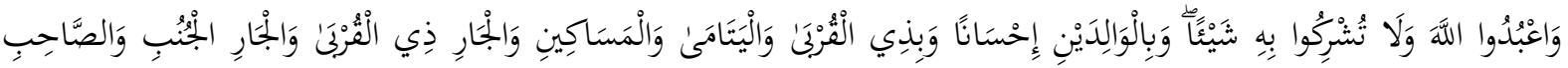

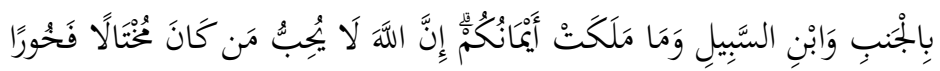

Sembahlah Allah dan janganlah kamu mempersekutukan-Nya dengan sesuatupun. dan berbuat baiklah kepada dua orang ibu-bapa, karib-kerabat, anak-anak yatim, orangorang miskin, tetangga yang dekat dan tetangga yang jauh dan teman sejawat, Ibnu sabildan hamba sahayamu. Sesungguhnya Allah tidak menyukai orang-orang yang sombong dan membangga-banggakan diri.

Ayat di atas menggambarkan golongan yang beredar dimasyarakat yang mesti mendapat perhatian lebih oleh sesama mereka agar kebersamaan dapat dijalin dan dibangun bersama untuk menghindari kecemburuan dan gejolak sosial yang dapat mengganggu hubungan yang harmonis sesama anggota masyarakat. Hal demikian akan berimplikasi pada nilai-nilai HAM.

\section{3). Membangun Hubungan Sosial (shilatur Rahim)}

Pondasi masyarakat yang kuat dan kokoh dapat dibangun melalui unit sosial dasar yakni keluarga yang tumbuh dalam suasana yang harmonis dan dapat merajut ikatan tali kekeluargaan (kerahiman) sesama mereka agar terhindar segala bentuk yang mengganggunya. Oleh karena itu hubungan kekeluargaan sebagai modal dasar untuk menjalin hubungan kemanusian semestinya harus harus diikat dan dilandasi oleh semangat kebersamaan yang didasari oleh ikatan ketuhanan. Dengan demikian, adanya tuntutan untuk menyelaraskan hubungan vertikal agar sejalan dengan hubungan horizontal yang dibangun berdasarkan tali kasih sayang sebagaimana yang dijelaskan dalam surat al-Nisâ/4:Isebagai berikut:

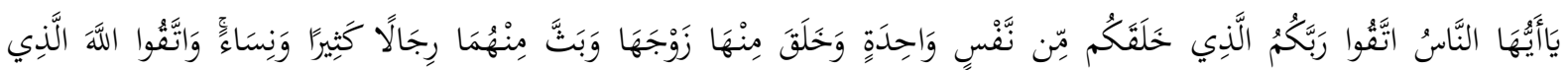

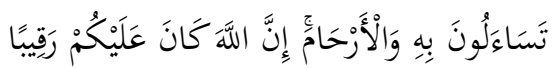

${ }^{51}$ Eka Hendry, Sosiologi Konflik: Telaah Teoritis Seputar Konflik dan Perdamaian (Pontianak: STAIN Pontianak Press, 2009), 151.

75 | al-ðurhan: Kajian Ilmu dan Pengembangan Budaya Al-Qur'an, Vol. 20, No. 1, Juni 2020: 50-79. 
Hai manusia bertakwalah kepada Tuhanmu yang telah menciptaknmu dari jiwa yang satu dan Allah menciptakn darinya istri (pasangan) dan dari keduanya Allah memperkembangbiakkan laki-laki dan perempuan menjadi banyak. Dan bertakwalah kepada Allah yang dengan (mempergunakan) nama-Nya kamu saling meminta satu sama lainya dan(peliharalah) hubungan shilat al- rahim. Sesungguhnya Allh selalu menjaga dan mengawasi kamu.(al-Nisâ'/4:1)

Ayat di atas mengisyarakat tentang kesatuan dari asal usul manusia dari satu keturunan yang dapat mendorong dan melahirkan kesatuan dalam masyarakat dalam ikatan persaudaraan kemanusiaan. Ayat di atas mendorong setiap invdividu untuk membangun ikatan sosial tanpa memandang sekat-sekat gender ( laki-laki maupun perempuan), ras (warna kulit,suku, budaya), keyakinan; beragama maupun tidak memiliki keyakinan dan lain sebagainya. Masing-masing pihak dituntut untuk menghadirkan rasa aman, ketenangan, kedamaian, kasih sayang sesama mereka dan saling menghormati hak-hak mereka.

Seandainya ayat di atas dapat dipahami dengan baik maka semua manusia akan menyadari bahwa mereka berasal dari Tuhan yang satu yang telah menganugrahkan kepada manusia dengan berbagai kenikmatan yang tidak terbatas dan lebih khusus lagi telah memberikan kepada mereka kebebasan dalam menentukan pilihan untuk bertindak dan berbuat bahkan untuk berkeyakinan sekalipun. Oleh sebab itu, pembukaan ayat di atas dimulai dengan kalimat ajakan yaitu ياأيهاالناس (wahai manusia) yang bersifat umum ditujukan pada semua manusia tanpa kecuali meskipun ayat tersebut Madaniyah yang lazimnya dimulai dengan yâ ayyuha 'Ia-dzîna âmanû ( wahai orang-orang beriman). Dalam ayat di atas diperjelas dan dipertegas bahwa keberadaan manusia sekarang ini yang telah mencapai jumlahnya milyaran dengan berbagai latar واحدة () belakang dan perbedaan, semuanya berasal pada mulanya dari jiwa yang satu نفس).

Sudah seharusnya kesamaan pandangan di atas tersebut menjadi prinsip dan sikap yang harus ditanamkan pada setiap individu agar bangunan ikatan tali kekeluargaan dan persaudaraan manusia dapat dihindari dari perselisihan dan pertikaian yang seharusnya tidak perlu terjadi akibat dari perbedaan-perbedaan yang ada. Sejatinya perbedaan-perbedaan yang ada harus dapat dimengerti sebagai suatu keniscayaan dari penyebaran manusia di permukaan bumi dan dipengaruhi oleh letak geografis, sosiologis dan antropologis. ${ }^{52}$ Pentingnya menjaga ikatan sosial tersebut sebagaimana di jelaskan di atas maka hubungan kemanusiaan diletakan sesudah perintah taqwa kepada Allah SWT.

4). Membangun Kekuatan Spritual

Untuk menerapkan langkah-langkah di atas kekuatan spiritual memegang peranan penting karena sebagai motor penggerak dan pendorong yang bekerja tanpa pamrih untuk tujuan selain Allah SWT. Kekuatan spiritual harus dibangun dan

$5^{2}$ Sesungguhnya perbedaan merupakan kodrat dan suatu keniscayaan yang menyertai kehidupan manusia yang tidak mungkin untuk dihndari, sebagaimana yang dijelaskan dalam surat alHujûrât/49:13. al-Nisa'/4:1 dan al-Hujûrât/49:13 keduanya memerintahkan kesatuan, persatuan antar sesama dan melarang pertikaian. Akan tetapi, penekanannya berbeda. al-Nisâ'/4:1 memerintahkan persatuan, karena semua manusia berasal dari satu jiwa, sedangkan al-Hujurât/49:13 melarang pertikaian dan perpecahan antar individu atau kelompok, karena yang paling mulia di sisi Allah adalah hamba-Nya yang paling taqwa.. 
disemai di dalam hati terlebih dahulu sebelum melangkah terlebih jauh. Ada banyak cara untuk membangun dan mempertebal kekuatan spiritual. Pertama, iman yang kuat yang didasari pada pemahaman yang benar tentang keesaan Allah SWT dan selalu bersandar pada Allah SWT. Kedua, senantiasa mendekatkan diri pada Allah SWT dengan memperbanyak ibadah dan membangun komunikasi yang intens dengan memperbanyak amalan-amalan dan ibadah sunnah selain ibadah wajib yang harus ditunaikan.

Ketiga, membersihkan hati dari penyakit-penyakitnya dengan senantiasa melakukan penyucian diri dan mengongsongkannya dari selain Allah SWT. Karena hati merupakan tempat dan sumber kekuatan spiritual. Melakukan penyucian terhadap (tazkiah) hati akan menempatkan kesadaran tinggi untuk senantiasa berhubungan dengan Allah dan selalu merasa diawasi oleh Allah SWT sehingga menjauhkan seseorang dari pekerjaan-pekerjaan yang sia-sia apalagi melanggar larangan-larangannya.

Kekuatan spiritual menjadi inti dan dasarnya, sementara selainnya hanya sebatas pelengkap dan penunjang. Dalam hadis di atas Nabi mengingatkan dan menjelaskan untuk mendapatkan kekuatan spiritual yang besar dan kokoh adalah dengan melakukan shalat malam ketika manusia semuanya dalam keadaan tidur sesuai firman Allah sebagai berikut,

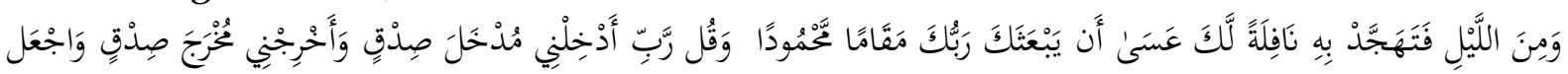

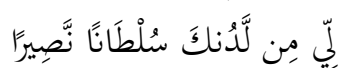

Dan pada sebahagian malam hari bersembahyang tahajudlah kamu sebagai suatu ibadah tambahan bagimu; mudah-mudahan Tuhan-mu mengangkat kamu ke tempat yang terpuji. Dan katakanlah: "Ya Tuhan-ku, masukkanlah aku secara masuk yang benar dan keluarkanlah (pula) aku secara keluar yang benar dan berikanlah kepadaku dari sisi Engkau kekuasaan yang menolong. (al-Isra'/17:79-80)

\section{Kesimpulan}

Sesungguhnya Islam itu adalah agama pembela, menjaga dan melindungi hak asasi manusia karena hak asasi manusia adalah misi utama dari ajaran Islam. Hadirnya Islam misi utamanya adalah untuk kemaslahatan manusia dan menyelamatkannya dari segala sesuatu yang membahayakannya terutama terhadap pelanggaran hak asasi manusia. Oleh karena itu untuk menjaga dan melindungi hak asasi manusia Allah SWT telah menyiapkan tiga komponen penting bagi manusia khususnya bagi umat Islam yaitu akidah, syariat dan akhlak. Ketiganya memiliki fungsinya masing-masing dengan segala kandungan yang terdapat di dalamnya yang dapat dipelajari dengan tersendiri namun tidak dapat dipisahkan karena satu sama lainnya saling kait mengait dan mempunyai ikatan yang erat. 


\section{DAFTAR PUSTAKA}

Abul A’la Maududi, Maulana. Hak-Hak Asasi Manusia dalam Islam. Jakarta: Bumi Aksara, 200o.

Al-Baihaqî, Ahmad bin Husein Abû Bakar. Sunan al-Kubrâ li al-Baihaqî, Edti. Mustafa 'Abd Qâdir al-Athâ'. Mekkah: Maktabah Dâr al-Bâz, 1994.

Alkatiri, Zeffry. "Multikultur dan Multiperspektif dalam HAM Internasional", Wacana 8, no. 2 (2006)

Al-Faruqi. Ismail Raji Tauhid. Bandung: Penerbit Pustaka, 1982

Al-Naisaburi, Abul Husain Muslim bin al-Hajjaj al-Qusyairi. Shahîh Muslim. Beirut: Dâr al-Fikr, 1414 H/1993 M.

Al-Razi Fakhr al-Din, Muhammad. Tafsîr al-Kabîr wa Mafâtîh al-Gayb. Beirut: DâralFikr, $1415 \mathrm{H} / 1995 \mathrm{M}$.

Al-Sirjani, Raghib. Rasulullah Teladan Untuk Semesta Alam, Penerjamah, Arif Rahman Hakim. Sukoharjo:Insan Kamil Solo, 2011.

An-Na'im, Abdullahi Ahmed. Dekonstruksi Syariah: Wacana Kebebasan Sipil, Hak Asasi Manusia, dan Hubungan Internasional dalam Islam. Yogyakarta: LKis, 2004 .

Ash Shiddieqy, T. Muhammad Hasbi. Islam dan Hak Asasi Manusia. Semarang: PT Pustaka Rizki Putra, 1999.

Dato Haron Din. Rujukan EfektipAkhlak Mulia. Sabah:Publishing House, 2007.

Dalizar Putra. Hak Asasi Manusia Menurut Al-Qur'an. Jakarta: PT. Husna Zakra, 1999.

Davidson, Scott. Hak Asasi Manusia. Jakarta: Grafitti, 2008.

Davies, Peter. Hak Asasi Manusia: Sebuah Bunga Rampai. Jakarta: Yayasan Obor Indonesia, 1994.

Fariss, Christopher J. "Respect for Human Rights has Improved Over Time: Modeling the Changing Standard of Accountability", American Political Science Association 108, no. 2 (2014)

Ibn Hisyâm. Sîrah Ibn Hisyâm. Mesir: Syirkat al-Maktabah dan Matba'ah Mustafâ alBâbî dan Anak-Anaknya, th. 1955 .

Ibn 'Asyûr, Muhammad al-Tâhir. Maqâsid al-Syari'at al-Islamiyyah. Amman: Dar alNafais, t.th.

Kamali, Mohammad Hashim. Kebebasan Berpendapat dalam Islam, terjemahan Eva Y. Nukman dan Fathiyah Basri. Bandung: Penerbit Mizan, 1996.

Kosasih, Ahmad. HAM dalam Perspektif Islam. Jakarta: Salemba Diniyah, 2003.

Lopa, Baharudin. Al-Qur'an dan Hak Asasi Manusia. Yogyakarta: Dana Bakti Prima Yaksa 1996.

Lowy, Michael. Teologi Pembebasan. Yogyakarta: Pustaka Pelajar, 2003.

Mayer, Ann Elizabeth. Islam and Human Rights Tradition and Politics. Colorado: Westview Press.

Myers, D. G, Social psychology. Ninth edition. New York, NY: McGraw-Hill, 2008.

Monib, Mohammad dan Islah Bahrawi. Islam dan Hak Asasi Manusia dalam Pandangan Nurcholish Madjid. Jakarta: PT Gramedia Pustaka Utama, 2011.

Putra, Dalizar. Hak Asasi Manusia menurut Al-Qur"an. Jakarta: PT Al-Husna Zikra, 1995 .

Qurtubi, Imam. al-Jāmi' li Ahkām al-Qur'ān. Qahirah: Darul Kutub al-Misriyyah 1964. 
Salim, Muhammad Ibrahim. Perempuan-Perempuan Mulia di Sekitar Rasullullah shallallâhu 'alaihi wasalam. Jakarta: Gema Insani Press 2002.

Shihab, Quraish. Membumikan Al-qur"an: Fungsi dan Peran Wahyu dalam Kehidupan Masyarakat. Bandung: Mizan, 1992.

Smith, Rhona K.M. (et.al). Hukum Hak Asasi Manusia. Yogyakarta: PUSHAM UII, 2008.

Shaltut, Mahmud. Akidah dan Syariat Islam. Jakarta: Bumi Aksara, 1994.

Simmons, Beth A. "The Future of the Human Rights Movement". Ethics $\mathcal{E}$ International Affairs 28, Iss. 2, (2014): 183-196)

Wan Mohd Nor Wan Daud, Filsafat dan Praktik Pendidikan Islam Syed Muhammad Naquib al-Attas. Bandung: Mizan 2003. 